\begin{tabular}{|c|c|c|}
\hline Received 02.05.2021 & \multirow{3}{*}{ Research Article } & \multirow{3}{*}{$\begin{array}{c}\text { JOTS } \\
5 / 2 \\
\text { 2021: } 311-358\end{array}$} \\
\hline Accepted 25.05.2021 & & \\
\hline Published 24.07.2021 & & \\
\hline
\end{tabular}

\title{
Seçili Anlam Alanındaki Kök Dal Biçimlere Ulaşmada Yeni Bir Yöntem Denemesi
}

\author{
Attempting a New Method to Obtain Root Allomorphs on a Selected Area of Meaning
}

\author{
Deniz DEMİRYAKAN \\ İstanbul/Turkey \\ E-mail:demiryakan@hotmail.com
}

The word roots, bearing the traces of the age of the formation of languages and language families, are structures that were initially monosyllabic in all languages. Although the meeting of these monosyllabic structures with writing is at different conditions and times for each language, the different utterances (root allomorph) of these monosyllabic structures occurred long before writing. In these periods when linguistic productivity was limited, naming the same information with different utterances brought along root allomorphs, all born from the same basic root. It is also the purpose of the article to determine these root and branch forms in a functional way. Contrary to traditional methods, in this article, it is tried to reach the purpose by searching the source dictionary with twelve single and double syllable bases, seven pre-sound entries within the scope of the selected meaning area.

Key Words: root, root allomorph, root etymons, cognates.

\footnotetext{
ORCID ID: 0000-0002-3565-3314.
} 


\section{Giriş}

Dillerin ve dil ailelerinin oluşma çağlarının izlerini taşıyan sözcük kökleri, başlangıçta bütün dillerde tek heceli olan yapılardır. Bu tek heceli yapıların yazı ile buluşması her dil için farklı koşullarda ve zamanlarda olsa da söz konusu tek heceli yapıların değişik söyleyişleri (kök dal biçimleri) yazıdan çok önce oluşmuştur. Dilsel üretkenliğin sınırlı olduğu bu dönemlerde aynı bilginin değişik söyleyişlerle adlandırılması, hepsi aynı temel kökten doğan kök dal biçimleri de beraberinde getirmiştir. Sözcük kök ve gövdelerinin farklı nedenlerle oluşan bu kök dal biçimleriyle ilgili çalışma sayısı az olmakla birlikte bu çalışmaların bulguları sınırlı sayıda veri içermektedir. Bu sınırlılığa neden olan temel etkense, çalışmaların sözcük kök ve gövdelerine yalnızca biçimsel açıdan yaklaşma eğilimi nedeniyle kök dal biçimlere ulaşma sürecinde anlamın dışlanmasıyla ilgilidir. Diğer bir durum da sözcük kök veya gövdesine biçimsel açıdan yaklaşıldığında sözcükteki herhangi bir ses değişiminin kanıtlanmış (veya saptanmış) ses denklikleri çerçevesinde bir dağılım göstermesi gerektiği düşüncesidir. Her sesin her sesle nöbetleşebileceği varsayımından hareketle sözcük kök ve gövdelerine yaklaşıldığında kök ve gövdelere ait olan kök dal biçimlerin beklenenden çok daha fazla olduğu bu çalışma özelinde örneklendirilmiştir. Doğası gereği karmaşık olan bu sürecin etkin ve işlevsel bir biçimde betimlenebilmesi için sözcük kök veya gövdesinin kök dal biçimlerinin sözcük kök boyutunun da altına inilerek, anlamın odakta olması koşuluyla incelenmesi zorunludur. Bu nedenle, çalışmada, seçili anlam alanı çerçevesinde tekli ve ikili toplam on iki hece tabanı, yedi önses girişi ile kaynak sözlükte tarama yapılmıştır. Tarama sonrasında elde edilen verilerinin işlevsel bir biçimde aktarılabilmesi için sürecin işleyişini ve yöntemini anlatan bir dizi açılama ikinci başlık altında verilmeden önce aşağıda, kök dal biçim terimine genel hatlarıyla değinilmiştir.

\section{Kök Dal Biçim (Root Allomorphs) Terimi}

Kök dal biçim terimiyle ilgili açılama yapılmadan önce söz konusu terimi oluşturan sözcüklere, bazı tematik sözlüklerden hareketle değinmek yararlı olacaktır:

Bunlardan ilki, kök (root) terimidir. 


\section{Kök Sözler (Roots)}

Kökler, dillerin ve dil ailelerinin oluşma çağlarından kalma ve çoğu, bütün dillerde tek heceli olan yapılardır. Söz köklerindeki söz-varlık ilişkisi nedensiz (arbitrary, nonpredictable) bir ilişki olmasına karşılık, çeşitli türetme yolları ve anlam değiştirmeleriyle kurulan önceki bilgi-sonraki bilgi veya alt bilgi-üst bilgi adlandırmaları, yansıma sözler gibi, nedenli (non-arbitrary, predictable) adlandırmalardır (Karaağaç, 2011: 719).

kök (Alm. Wurzel; Fr. racine; İng. root): Kelimelerin bütün yapım ve çekim eklerini çıkardıktan sonra ayrılamayan ve esas (temel) anlamı taşıyan bölümü: ye-, sor-, kış, el (< elig), al-, dur-, yol, ver- vb. (Korkmaz, 1992: 104).

kök (root) biçimbilim: Bir sözcükbiçimde bütün çekimsel ve türetimsel parçalar çıktıktan sonra kalan bölüm; örn. ev, su, al, gel. Bu anlamda kök, sözlükbirimin parçalanamaz, en küçük biçimidir (İmer et al., 2011: 182).

kök (Alm. wurzel, Fr. racine, İng. root): Bir sözcük ailesinin çeşitli biçimlerinde yer alan, tarihsel dilbilimin, değişik türevleri açıklamak için yararlandığı, çoğu kez gövdeyle özdeşleşen, sözcükten dilbilgisi ve yapım öğeleri çıkarılarak elde edilen bölüm. Bu kavram daha çok artsüremli dilbilimde kullanılır ve değişik gerçekleşmeleri olan, belli bir kavramı anlatan soyut bir biçim olarak görülür. Ne var ki, birçok dilbilimcinin bu terime köken anlamı verdiği de bir gerçektir. bk. köken (Vardar, 2002: 138).

dal (allo-) terimiyle ilgili tanımlardan bazıları aşağıdaki gibidir:

dal (allo-): Dildeki birliğin kimliğini etkilemeyen, anlam veya görev değişikliğine yol açmayan, fark edilir her bir değişikliğe gönderme yapmak için kullanılan bir terimdir. Dil biriminin biçimindeki değişiklik, birimin anlamı açısından ayırıcı değildir, yani anlamdaki hiçbir değişiklikle ilgili değildir. Ses, biçim, anlam ve yapıların dal biçimleri vardır ve bu dal biçimlerin bütünü, ses birimi, biçim birimi veya anlam birimlerini oluşturur; dal sesler (allophones), ses biriminin (phonem); dal biçimler (allomorphs), biçim biriminin (morphem); dal anlamlar (allosemes), anlam biriminin; dal titremler (allotone), titrem biriminin (intonem) sınırlarını çizerek alanlarını belirlerler. Böylece dilin bireysel veya bölgesel değişkenleri, tek ve ortak bir alanda buluşarak, iletişimi mümkün kılarlar. krş. değişken, dal ses, dal biçim, dal anlam (Karaağaç, 2011: 256).

altbirim(cik) (allo-) sesbilim, biçimbirim: Bir dil biriminin değişkesi; özellikle sesbilim ve biçimbilimde kullanılır, örneğin ölçünlü Türkçede ekmek sözcüğündeki kapalı [é] ve sen sözcüğündeki açık [e] sesleri, /e/ sesbiriminin altbiçimbirimcikleridir; [-ler] ve [-lar] altbirimleri Türkçe çoğulluk biçimbirimi \{-1Ar\}’ın altbirimleridir (İmer vd., 2011: 23).

Biçimbirim (morpheme) ile ilgili tematik sözlüklerdeki bazı tanımlamalar ise şöyledir: 
biçim birimi (morpheme): Dillerin tamamen saymaca olan ses birimleri, anlam değiştirici olmalarına karşılık, anlam taşıyıcı değildirler. Anlamı olan, anlam değiştirici veya anlam birleştirici olan ses veya ses demeti, biçim birimidir (Karaağaç, 2011: 193).

morfem (Alm. morphem; Fr. morpheme, İng. morpheme): Dilde daha küçük parçalara ayrılamayan anlamlı en küçük birim. oyuncu-luğ-umuz-un baş-ar-1-sı; gül-üş-me-ler-den; süt, balık, al, kan vb. (Korkmaz, 1992: 110).

biçimbirim (morpheme) biçimbilim Dilde anlamlı en küçük birim; örn. Kitap, masa, gözlük/kitaplar, masalar, gözlükler tümü de tek tek sözcükler olmakla birlikte çoğul eki alan ikinci kümedeki sözcükler iki biçimbirimden oluşurlar: kitap + çoğul $\rightarrow$ kitaplar. Biçimbirimler bağımlı ve bağımsız olmak üzere iki kümeye ayrılır. Yukarıdaki örneklerde kitap, masa, gözlük bağımsız biçimbirimlerdir, \{-lAr\} çoğul eki bağımlı biçimbirimdir. Biçimbirimleri oluşturan altbirimlere biçimbirimcik denir; örneğin $\{+1 \mathrm{Ar}\}$ çoğul biçimbirimi $\{-1 \mathrm{Ar}\}$ 'nn, -(n)in, -\{n)ün, (n) un, $\sim(\mathrm{n}) \mathrm{n}$ tamlayan biçimbirimi $\{-(\mathrm{n})$ In\}' $1 \mathrm{n}$ biçimbirimcikleri'dir. Bu anlamda biçimbirimler bu altbirimlerden oluşan bir soyutlamadır (İmer et al., 2011: 53).

biçimbirim (Alm. morphem, Fr. morpheme, İng. morpheme): 1. Anlambirimin sözlükbirime karşıt olarak, dilbilgisini ilgilendiren türü. 2. En küçük anlamlı birim, en küçük gösterge. Amerikalı dilbilimciler biçimbirim terimini ikinci anlamda kullanırlar. L. Bloomfield'de biçimbirim en küçük dilsel birimdir ve iki tür kapsar: Bağımsız biçimbirim tek başına sözce oluşturabilir; bağımlı biçimbirimse hiçbir zaman tek başına gerçekleşemez ve sözce oluşturamaz (Vardar, 2002: 42).

kök dal biçim (rooth allomorph; bazı sözlüklerdeki en yakın terim: allomorph) terimini oluşturan sözcükler, terimsel kullanımları açısından yukarıda tek tek açıklanmıştır. Söz konusu terimin tanımı ise yine aynı tematik sözlükler kanalıyla şu biçimde aktarılabilir:

\section{Kardeş Kökler [Kök Dal Biçim] (rooth etymons, cognates, rooth allomorphes)}

Dillerin söz türetme düzeneği gelişmeden ve diller yazıyla buluşmadan önce, aynı söz kökünün farklı söyleyişleri, komşu bilgileri adlandırmak için kullanılmıştır. Bu yüzden, söz kökleri, dillerin sözlüklerinde, eski şiveler arası bölgesel alıntıları ifade eden dal biçimleriyle birlikte yer alırlar ki bunlara kardeş kökler denir. Dil biliminde ve bilhassa da dil tarihi çalışmalarında, bir ortak dil, kök dil, ata dil (common language, proto-language, ancestor language, parent language) ve bir ilk biçim, eski biçim, asli biçim (main form, ancestral form, protomorpheme, archaic morpheme) sürekli gündemdedir. Dil ile yazı ilişkisi oldukça yeni devirlerde başladığı için, dile ait olan ilk ses, asli ses, kök ses ile ilk biçim, asli biçim, kök biçim terimlerinden, gerçek anlamda bir ilk, asli ve kök ses veya biçim'i değil, 
yazıya geçirilmiş en eski ses veya biçimi anlamak gerekmektedir; çünkü dil nasıl ki insanı tarihsel bir varlık durumuna getirmişse, dilin kendisini de kalıcı kılıp tarihselleştiren şey, yazıdır. Bu yüzden dil tarihi ile yazı tarihi iç içedir. En eski yazılı biçimlere dayanarak, bir dilin yazıdan önceki biçimlerini arama yöntemleri geliştirilmiş, dil tarihini, kendisinden çok daha genç olan yazının tarihinden binlerce yıl öncelere taşıma çalışmaları yapılmıştır. Yeniden kurma (reconstruction) veya iç ihya (internal reconstruction) yoluyla bir dilin tarih öncesine doğru yol almak, bir ölçüde mümkündür; fakat burada da genel ses biliminin işaret ettiği bir tuzağın varlığı söz konusudur. Bu tuzak, dilcilerin 'Eğer belirli bir ses birimi değişmesi meydana geliyorsa, bunun tersi de olabilir' veya 'Ses değişimi ile kaybolan ses ve biçimlerin, kısa bir süre sonra, başka bir ses değişimiyle tekrar ortaya çıkması' biçiminde sık sık ifade ettikleri gibi, dil hareketlerinin iki yönlü olabilmeleridir.

Görüldüğü gibi, bugün dilcilikte ilk, asli veya kök biçim ifadesinden anlamamız gereken, kayıtlı en eski biçim olmalıdır, yoksa bir dil unsurunun gerçekten ilk, asli, kök biçimini yakalamak, dil ile yazı arasındaki yaş farkı yüzünden, asla mümkün değildir. Dili kalıcı kılan, onu tarihsel bir varlık haline getiren, yazıdır. Bir dilin tarihi, o dilin yazı tarihiyle iç içedir. Kökler, dillerin ve dil ailelerinin oluşma çağlarından kalma ve çoğu, bütün dillerde tek heceli olan yapılardır. Bilindiği gibi, dillerin eski yapıları ancak yazı ile izlenebilmektedir; oysa resmin yazılaşması ve yazının dil ile buluşması, dillerin oluşum süreçlerine oranla, oldukça yeni olgulardır. Dillerin yazı ile buluşma tarihi, her dil için farklı olmuştur; fakat diller yazı ile buluştuklarında, kök yapılarında değişmeler, köklerin değişik söyleyişlerle ortaya çıkmış dal biçimleri çoktan oluşmuştu.

Kısacası, dillerin söz türetme düzenekleri gelişmeden önce, bir tür şiveler arası alıntıları ifade eden bu dal biçimlerin komşu bilgileri adlandırmak için kullanıldıklarını görmekteyiz. Böylece söz kökleri, dillerin sözlüklerinde, eski şiveler arası alıntıları ifade eden dal biçimleriyle birlikte yer alırlar. Bunlar kök dal biçimlerdir:

GT aş 'yemek' yal 'etoburların yiyeceği'; GT çiş 'çiş, sidik' işe- 'çiş yapmak' kaşan- '(at) işemek'; GT kañ 'baba' kañ, kagan 'kağan' aga 'büyük' apa, aba 'baba; abla'; GT abl'örtmek' aban- 'abanmak, kapanmak' avun- 'avunmak' yap- 'kapamak, örtmek; etmek, eylemek' yapağı 'yapağı' yaprak 'yaprak' kapa- 'kapamak' kapak 'kapak' kaba 'kaba, kalın; kaba dokunmuş kumaş' kebe 'örtü' kebit 'büfe' abaktı 'hapisane' kepenek 'kepenek' aban- 'abanmak' avun- 'avunmak' avut- 'avutmak' ubut 'edep' ut 'edep' 


\section{J(৫)}

utan- 'utanmak' uyal- 'utanmak' kapa- 'kapamak'; GT ad 'ad' adın 'başka, ayrı' ayır'ayırmak' tat 'yabancı' yad 'yabancı' kayır- 'ayırmak, kayırmak' kañır- 'ayırmak, kayırmak' kadak 'ayak' kadakla- 'peşinden gitmek' adak 'ayak' ayak 'ayak' yadagın > yayan 'ayak ile'; GT ob, oba 'parça' og- 'oğmak' opra- 'yipranmak' obruk 'çukur, dere' yıpran- 'yıpranmak' epri- 'yıpranmak' doğra- 'doğramak' avk-'ufalamak' abuşka 'yaşlı' ～uşak 'ufak, uşak' ufak 'ufak' uğur 'yol' çığır 'yol' tıkır 'yol' hırsız 'hırsız'; GT yük'yığmak' yükmek 'yığın, tomar' yok 'çok' yokuş 'yokuş' yığ- 'yığmak' yoğun 'yoğun' çok 'çok' yüksek 'yukarı' yukarı 'yüksek' öklit- 'çoğaltmak' öküş̧ 'çok' tomar 'tomar' tüg- 'toplamak' düğün 'toplant1' düğüm 'düğüm' tepe 'yığın' tömek 'yığın' tümen 'yığın; on bin' kop 'çok' köp 'çok'; GT ot 'ateş' otağ 'otağ' ocak 'ocak' oda 'oda' ütü 'ütü' oçın 'kıvılcım' kotar- 'pişirmek' odun 'odun'; GT eş 'eş' tuş 'eş' tüş 'eş' koşa 'eş, çift' koş- 'eşlemek' tüşün- 'düşünmek' koşma 'şiir; şiir türü' koşuk 'şiir' kuşak 'kuşak, sarg1' töle- 'ödemek' kölüsün 'ücret'; GT ışı- 'ş̧ımak' isın- 'ssınmak' alşs- 'tutuşmak; alışsmak' alev 'alev' yaltıra- 'parlamak' çaşın 'şimşek' ışık '1şık' şimşsek 'şimşek' yıldız 'yıldız' yıldırım 'yıldırım' yalım 'ateş' yaldız 'yaldız' yaltırı 'parlak' vb.

Dediğimiz gibi, diller yazı ile buluştuklarında bu kök dal biçimler çoktan oluşmuştu: Ar. garb 'batma; bat1' gurbet 'gurbet, ayrillk' garabet 'gariplik, tuhaflık'; Ar. kavl 'söz' kil 'arkasından konuşma' kal 'söyleme'; Far. huda 'tanrı' $\sim$ div 'dev' pad/padşah 'hükümdar' İng. god 'tanrı' father 'baba'. krş. akraba sözler (Karaağaç, 2011: 529-530).

Diğer tanımlar ise doğrudan kök dal biçim terimini açıklamamaktadır:

değişken şekil (Alm. allomorph; Fr. allomorphe; İng. allomorph): Aynı anlam ve görevdeki bir şekil bilgisi biriminin ses yapısı bakımından farklılaşan türü; şekil bilgisinin anlamlı bir küçük ögesi olan bir kelime kökünün veya belirli görevler ile buna eklenen bir ekin farklı ses yapısına girmiş olan şekli. Söz gelişi lehçe ve ağız ayrılıklarına göre ve çeşitli sebeplerle bazı köklerin bez/böz, er/ir 'erken', çez-/çöz, erte/örte 'ertesi gün'; baba/buba, bıldır/bildir 'geçen yıl', ıldız/yıldız/yulduz şekillerinde ses değişmesine uğraması. Aynı durum ekler için de söz konusudur. $\{-\mathrm{dX}\}$ veya $\{-\mathrm{tX}\}$ geçmiş zaman ekinin ünlü ve ünsüz uyumlarına bağlı olarak -di/-di, -du/-dü, -tı/-ti, -tu/-tü, \{-Duk\} geçmiş zaman sıfat-fiil ekinin yine aynı sebeplerle -dık/dik, -duk/-dük, -tık/-tik, -tuk/-tük şekillerine dönüşmesi gibi: aldı, ver-di, oku-du, gör-dü, aç-tı, biç-ti, tut-tu, öt-tü, tanı-dlk, bil-dik, tut-tuh (ğ)umuz iş, yürüdük (ğ)ümüz yol vb. (Korkmaz, 1992: 42).

Biçimbirimsel Değişke (Alm. Allomorph, Fr. allomorphe, İng. allomorph). Bir birime ilişkin göstergenin kapsadığı değişkelerin her biri (Vardar, 2002: 42)

Alıntılamalardan da görüleceği üzere kök dal biçim terimiyle ilgili gerek makalelerinde gerekse de Dil Bilim Terimleri Sözlügü̈nde en detaylı açılamayı yapan Karaağaç'tır.

Yine aynı sözlükten, alıntılanan kök dal biçim örnekleri aşağıdaki gibidir. 
çiş 'çiş, sidik' işe- 'çiş yapmak' kaşan- '(at) işemek'; kañ 'baba' kañ/kagan 'kağan' aga 'büyük' apa/aba 'baba; abla': ad 'ad' adın 'başka' ayır- 'ayırmak' tat/yad 'yabanc1' kayır- 'kayırmak, ayrı tutmak; sevmek' kañır- 'ayırmak, parçalamak'; yap- 'örtmek' aban- 'üzerine kapanmak' avun- 'avunmak' avut- 'avutmak' ubit, ut 'utanma, edep, haya' utan- / uyal- 'utanmak' kapa- 'kapamak, örtmek'; opra- 'yıpranmak' obruk 'oyuk, çukur, dere' yıpran- 'yıpranmak' epri- 'yıpranmak' doğra- 'doğramak' avk- 'ovalayıp yıpratmak' abuşka 'ihtiyar' uşak 'ufak' ufak 'ufak' vb. (Karaağaç, 2011: 256-257).

Burada koyu renkle dizilmiş olan sözcükler, belirli ses denklikleri çerçevesinde yazılı dönemden önce veya sonra bazı kök dal biçimlere dönüşmüştür. Neredeyse bütün dillerin ve bu dillere ait olan söz malzemelerinin tek heceli köklerden doğduğu göz önünde bulundurulduğunda yukarıdaki kök dal biçimlerin daha fazla olması gerekmektedir. Bunun için de sözcük kök ve gövdelerine hece boyutunda, sınırları belirlenmiş anlam alanı çerçevesinde yaklaşmaya çalışmak daha işlevsel olacaktır. Çalışmanın bundan sonraki bölümünde, giriş kısmında bahsedilen sayıltılara erişmek için yapılacak olan iş ve işlemlerin hangi yöntemsel süreçlerle gerçekleştirileceğine değinilecektir.

\section{Yöntem}

\subsection{Anlam Alanin Belirlenmesi}

Kök dal biçimler taranırken aşağıdaki anlam alanları çerçevesinde hareket edilmiştir. Burada özellikle dikkat edilen nokta sözcük kök veya gövdesinin yukarı/olumlayan $(\boldsymbol{\Lambda})$ ve aşağı/olumsuzlayan $(\boldsymbol{\nabla})$ yönelimlerinin her ikisinin de taranarak ilgili tabloya alınmasıdır. Türkçe gibi varsıl dillerde sözcüğün kök ve gövdesinin 'ikiuçlu' çıktılar vermesi beklendik bir durumdur. Öyle ki yükleeylemi var ise boşalt- eylemi; bağla- eylemi var ise çöz- eylemi; topla- eylemi var ise dağıt-, saç- eylemi bu listede olmak zorundadır. Yine, dip sözcügü var ise tepe sözcügü; yüksek sözcüğü var ise alçak sözcüğü bir arada değerlendirilmesi gereken dil ve anlam malzemelerdir. $\boldsymbol{\Lambda}$ ve $\boldsymbol{\nabla}$ yöneliminden ne kastedilmeye çalışıldığı aşağıdaki listede herhangi bir sıra gözetilmeden verilmiştir: 


\section{I(B)}

\begin{tabular}{|c|c|}
\hline$\Delta$ & $\nabla(\mathrm{Ass}$ \\
\hline $\begin{array}{l}\text { yük, yükle-; } \\
\text { ylğ-, yığın; öbek, küme; } \\
\text { birik-, birikinti; } \\
\text { top, topla-; } \\
\text { yüksel-, yüksek; } \\
\text { çık-, üst, yukar, tepe vb. } \\
\text { tak-, ekle-; } \\
\text { bağ, ip; bağla-; } \\
\text { çok, çoğalt-; } \\
\text { geniş vb.; } \\
\text { ön; } \\
\text { ilk; } \\
\text { aç-, yap-; } \\
\text { ile biçim yönüyle yuvarlak ve genelde büyük } \\
\text { insan dışı canlı ve nesneler. }\end{array}$ & $\begin{array}{l}\text { yık-; } \\
\text { boz-; } \\
\text { eğ- } \\
\text { kes-, biç- az, azalt-, dök-; } \\
\text { boş, boşalt-, dağıt-, savur- çöz-, artt-; } \\
\text { çak-, sapla-; } \\
\text { böl-, parçala-, kır-; } \\
\text { kaz-, kazı-; } \\
\text { kök, dip, kaynak, aşağı, alt; } \\
\text { dar vb.; } \\
\text { derin, arka, son vb. } \\
\text { döv-, vur; } \\
\text { ile biçim yönüyle dar ve uzun ve genelde küçük } \\
\text { insan dışı canlı ve nesneler. }\end{array}$ \\
\hline
\end{tabular}

Tablo 1: Seçili Anlam Alanları

Tabloda verilen anlam alanları çerçevesinde ilgili sözlükte yapılacak kök dal biçim taramasında hangi hece tabanlarının ve önses girişlerinin kullanılacağı bilgisi aşağıdaki gibidir.

\subsection{Hece Maddelerinin Belirlenmesi}

Aşağıda, kök dal biçimlere hangi hece tabanlarıyla erişileceğinin bilgisi verilmiştir:

\begin{tabular}{|c|c|c|c|c|c|}
\hline$\overline{~ h 1}$ & $\overline{~ h 3}$ & $\overline{h_{5}}$ & $\overline{h_{7}}$ & $\overline{~ h 9}$ & $\overline{~ h 11}$ \\
\hline $\mathrm{a}, \mathrm{e}$ & $\mathrm{aç}, \mathrm{eç}$ & al, el & $\begin{array}{c}\text { an, en } \\
\mathrm{n} \sim \mathrm{y}\end{array}$ & $\begin{array}{c}\text { aş, eş, } \\
\mathbf{s} \sim \text { ș }\end{array}$ & av, ev \\
\hline $1, \mathrm{i}$ & lç, iç & ll, il & $\begin{array}{c}\text { in, in } \\
\mathrm{n} \sim \mathrm{y}\end{array}$ & $\begin{array}{l}\text { 1ş, iş } \\
\mathrm{S} \sim \mathrm{S}\end{array}$ & lv, iv \\
\hline$\overline{\mathrm{u}, \ddot{\mathrm{u}}}$ & uç, üç & $\overline{\mathrm{ull}, \mathrm{ül}}$ & $\begin{array}{c}\text { un, ün } \\
\mathrm{n} \sim \mathrm{y}\end{array}$ & $\begin{array}{c}\text { uş, üş } \\
\mathrm{S} \sim \mathrm{S}\end{array}$ & $\overline{\mathrm{uuv}, \mathrm{üv}}$ \\
\hline$\overline{\mathrm{o}, \ddot{\mathrm{o}}}$ & oç, öç & $\overline{\text { ol, öl }}$ & $\begin{array}{c}\text { on, ön } \\
n \sim \mathrm{n}\end{array}$ & $\begin{array}{c}\text { OŞ, öş } \\
\mathrm{S} \sim \mathrm{S}\end{array}$ & $\overline{\text { ov, öv }}$ \\
\hline$\overline{~ h 2}$ & $\overline{\mathrm{h4}}$ & $\overline{\overline{h 6}}$ & $\overline{~ h 8}$ & h1o & $\overline{\mathrm{h12}}$ \\
\hline $\begin{array}{c}a b, e b \\
b \sim p \\
\end{array}$ & $\begin{array}{c}\text { ak, ek } \\
\mathrm{k} \sim \mathrm{g} \\
\end{array}$ & $\overline{c \text { am, em }}$ & $\overline{\text { ar, er }}$ & $\begin{array}{c}\text { at, et; ad, ed } \\
\text { d y } \\
\end{array}$ & 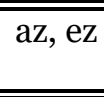 \\
\hline $\begin{array}{l}\mathrm{lb}, \mathrm{ib} \\
\mathrm{b} \sim \mathrm{p} \\
\end{array}$ & $\begin{array}{c}\mathrm{lk}, \mathrm{ik} \\
\mathrm{k} \sim \mathrm{g}\end{array}$ & $\mathrm{im}, \mathrm{im}$ & ir, ir & $\begin{array}{c}\text { it, it; id, id } \\
\text { d } \sim y\end{array}$ & $\overline{1 \mathrm{Iz}, \mathrm{iz}}$ \\
\hline $\begin{array}{c}\mathrm{ub}, \mathrm{üb} \\
\mathrm{b} \sim \mathrm{p}\end{array}$ & $\begin{array}{c}\mathrm{uk}, \text { ük } \\
\mathrm{k} \sim \mathrm{g}\end{array}$ & "um, üm & u ur, ür & $\begin{array}{c}\text { ut, üt; } \\
\text { ud, üd } \\
\text { d } \sim \mathrm{y}\end{array}$ & 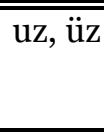 \\
\hline ob, öb & $\begin{array}{ll}\text { ok, ök } \\
\end{array}$ & om, öm & or, ör & ot,öt; od, öd & $\overline{\mathrm{Oz}, \mathrm{öz}}$ \\
\hline
\end{tabular}




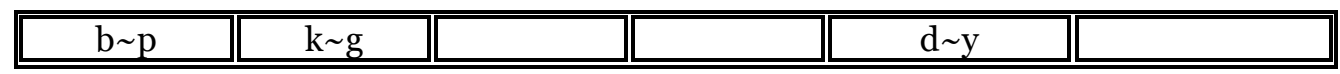

Tablo 2: Hece Maddeleri

\section{3 Önseslerin Belirlenmesi}

Tekli ve ikili hece tabanları, aşağıdaki önseslerle (ö1, ö2...ö7) birlikte kesiştirilerek ilk maddede sınırları çizilen anlam alanları çerçevesinde kök dal biçimlere ulaşmak amacıyla kullanılmıştır.

\begin{tabular}{|c|c|c|c|c|c|}
\hline ö1 & ö2 & ö3 & $\ddot{04}$ & ö5 & $\ddot{06}$ \\
\hline$y^{-}$ & ç- & $\mathrm{s}^{-}$, ş- & $t-$ & b- & k- \\
\hline
\end{tabular}

Tablo 3: Önses Girişleri

\subsection{Kök Dal Biçim Taraması Yapılacak Olan Kaynak Sözlüğün} Belirlenmesi ve Söz Konusu Yöntemin $\imath k-i k$ Hece Tabanında Örnek Olarak Uygulanması

Türkçenin etimolojisi üzerine Türkiye'de ve yurt dışında pek çok çalışma yapılmış olup bunlardan en önemlisi Türk dilinin XIII. yüzyıla kadar olan söz varlığını inceleyen Clauson'un An Etymological Dictionary of Pre-Thirteenth Century Turkish ( $\rightarrow$ EDPT) adlı eseridir. Bu özelliğinden dolayı sözlük, çalışmada kaynak sözlük olarak kullanılmıştır. Seçili anlam alanı çerçevesinde hece tabanı ve önses girişlerinin kesişimi (bir arada kullanımı), yukarıda adı geçen sözlükte aranmış ve koşullara uygun olan sözcük kök ve gövdeleri tabloya anlamları, sayfa numaraları ve yönelimleri $(\boldsymbol{\Lambda} \boldsymbol{\nabla})$ ile birlikte alınmıştır. Anlam alanı veya biçimsel açıdan belirlenen koşullara, diğerlerine nazaran daha az uyum sağlayan bazı sözcük kök ve gövdelerinin başına '?' işareti konulmuştur.

Buraya kadar dile getirilen tüm durumlar $\imath k-i k$ hece tabanında uygulandığında şöyle bir tablo elde edilecektir:

\begin{tabular}{|c|c|c|c|c|c|c|c|}
\hline & ö1 & ö2 & ö3 & ö4 & ö5 & ö6 & ö7 \\
\hline & $\varnothing$ & $y-$ & ç- & s-, s- $^{-}$ & $t-$ & b- & $\mathrm{k}-$ \\
\hline $\begin{array}{l}i k, \\
i k \\
k \sim g\end{array}$ & $\begin{array}{l}\text { lg- 'ylğ- } \\
\text { mak, piht1- } \\
\text { laşmak' } \\
\text { (EDPT } \\
77 \Delta \text { ) }\end{array}$ & $\begin{array}{l}\text { ylk- 'ylk- } \\
\text { mak' } \\
(\text { EDPT } \\
897 \mathbf{V})\end{array}$ & $\begin{array}{l}\text { çık'tam, } \\
\text { bütün; ta- } \\
\text { mamen, } \\
\text { bütünüyle' } \\
\text { (EDPT }\end{array}$ & $\begin{array}{c}\text { sik-'slk- } \\
\text { mak' } \\
(\text { EDPT } \\
804 \mathbf{\nabla})\end{array}$ & $\begin{array}{l}\text { tzk-'dol- } \\
\text { durmak' } \\
\text { (EDPT } \\
465 \text { ム) }\end{array}$ & $\begin{array}{l}\text { ?bik- 'bik- } \\
\text { mak' } \\
\text { (EDPT } \\
316 \boldsymbol{\nabla} \text { ) }\end{array}$ & $\begin{array}{l}\text { kik- 'birbi- } \\
\text { rine sürt- } \\
\text { mek, bile- } \\
\text { mek' bk. } \\
\text { kikşür- }\end{array}$ \\
\hline & & 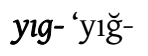 & $404 \boldsymbol{\Delta})$ & stka- 's1- & tıg- 'kes- & bikın & (EDPT \\
\hline
\end{tabular}




\begin{tabular}{|c|c|c|c|c|c|c|}
\hline $\begin{array}{l}\text { 'gaç 'or- } \\
\text { man' } \\
\text { (EDPT } \\
79 \Delta)\end{array}$ & $\begin{array}{l}\text { mak' } \\
\text { (EDPT } \\
897 \mathbf{\Lambda}) \\
\text { yıgaç 'or- } \\
\text { man' } \\
\text { (EDPT } \\
899 \mathbf{\Lambda}) \\
\text { yigi 'dar, } \\
\text { yoğun' } \\
\text { (EDPT } \\
911 \mathbf{\Delta} \text { ) }\end{array}$ & 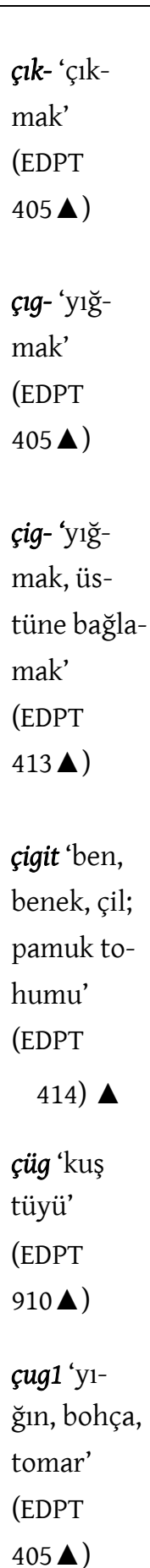 & $\begin{array}{c}\text { ğamak, s1- } \\
\text { vazlamak, } \\
\text { okşamak' } \\
\text { (EDPT } \\
806 \text { ム) } \\
\text { sıg 'sığ- } \\
\text { mak' } \\
\text { (EDPT } \\
804 \mathbf{\Lambda}) \\
\\
\text { sigil/sögöl } \\
\text { 'siğil, } \\
\text { yumru, şiş- } \\
\text { lik; kabar- } \\
\text { cık, si- } \\
\text { vilce’ } \\
\text { (EDPT } \\
\text { 820 V) }\end{array}$ & $\begin{array}{l}\text { kinliğini } \\
\text { yitirmek; } \\
\text { örtüp sak- } \\
\text { lamak; bo- } \\
\text { yun eğ- } \\
\text { mek’ } \\
\text { (EDPT } \\
465 \mathbf{\nabla} \text { ) } \\
\text { tik 'dik; } \\
\text { düz’ } \\
\text { (EDPT } \\
475 \mathbf{\Delta} \text { ) } \\
\text { tik- ‘dik- } \\
\text { mek’ } \\
\text { (EDPT } \\
476 \mathbf{\Delta} \text { ) }\end{array}$ & $\begin{array}{l}\text { 'kalça' } \\
(\mathrm{EDPT} \\
316 \mathbf{\Delta}) \\
\text { bıgrıg 'tu- } \\
\text { lum, torba' } \\
(\mathrm{EDPT} \\
318 \mathbf{\Delta})\end{array}$ & \begin{tabular}{|l}
$710 \mathbf{\nabla})$ \\
kıglat- \\
'gübrelet- \\
mek' bk. \\
kıg \\
'gübre' \\
(EDPT \\
$610 \mathbf{\Lambda}$ )
\end{tabular} \\
\hline
\end{tabular}

Tablo 4: Uygulama Çalışması

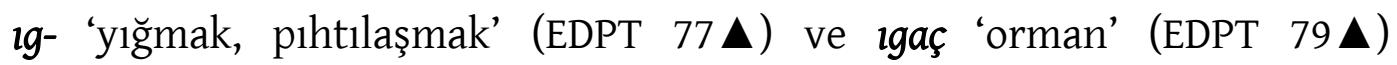
sözcüklerinin aynı sütun içinde yer alması onların arkaik yapısındaki kök hece ile ilgilidir. Her ikisi de bir şeyin çokluğunu, fazlalığını vb. ifade etmektedir. Önses $y$ - sütununda yer alan yıg- 'yığmak' (EDPT 897 A); yıgaç 'orman' (EDPT 


\section{J(৫)}

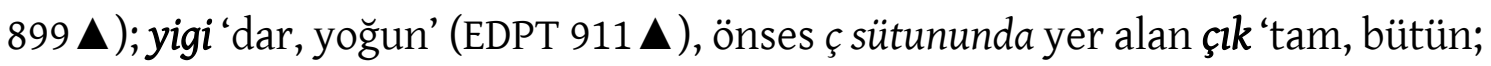
tamamen, bütünüyle' (EDPT $404 \mathbf{\Lambda}$ ); çık- 'çıkmak' (EDPT $405 \mathbf{\Lambda}$ ); çıg- 'yığmak'

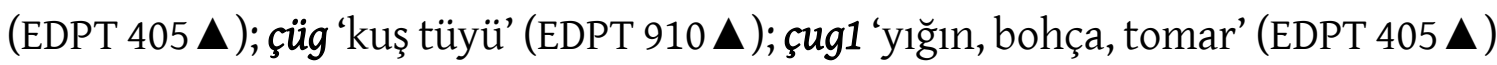
ve ön ses s-, t-, b-, k- sütunlarında yer alan sigil/sögöl 'siğil, yumru, şişlik; kabarcık,

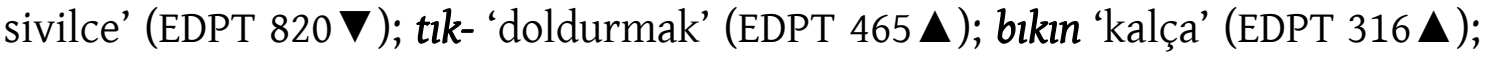
bıgrig 'tulum, torba' (EDPT $318 \mathbf{\Lambda}$ ); kıglat-'gübreletmek' bk. kıg 'gübre' (EDPT 610 \) sözcükleri yine aynı anlam alanında olup tek bir kök heceden doğmuş olmalıdırlar.

Tablo 4'te dikkat çeken durumlardan biri de $y \imath k$ - 'yıkmak' (EDPT $897 \boldsymbol{\nabla}$ ) ve yıg- 'yığmak' (EDPT 897 ム) eylemlerinin aynı sütün içinde dilin diyalektik yapısı gereği yer almasıdır. Dildeki az çaba ilkesi gereği tek hecenin dolayısıyla da onun kaynaklık ettiği sözcük kök ve gövdelerinin $\boldsymbol{\Lambda}$ ve $\boldsymbol{\nabla}$ uçlu yönelimlerinin olması dilin işleyişi açısından doğaldır. sık- ‘sıkmak’ (EDPT 804 V) eylemi parantez içinde görüleceği üzere $\boldsymbol{\nabla}$ yönelimlidir. Bir nesnenin sıkılması, sıkıştırılması sonucunda nesnenin herhangi bir yerinde yığılmalar, kümelenmeler olması beklenecektir. Bazen de kik- 'birbirine sürtmek, bilemek' bk. kikşür- (EDPT 710 V) eyleminde görüleceği üzere tümüyle karşıt bir kök dal biçim ortaya çıkacaktır.

Sözlük taraması sonucu elde edilen 654 sözcük kök ve gövdesinin Tablo 4'teki gibi tek tek detaylandırılması mümkün olamayacağından yukarıdaki açıklamalar ışığında Tablo 5'in dikkatle incelenmesi faydalı olacaktır.

\section{Sözlük Maddelerinin Taranması Sonrası Oluşan Kök Dal Biçim}

\section{Tablosu}

\begin{tabular}{|c|c|c|c|c|c|c|c|}
\hline & ö1 & ö2 & ö3 & ö4 & ö5 & $\ddot{06}$ & $\ddot{0} 7$ \\
\hline & Q- & $y-$ & ç- & $\mathrm{s}^{-}, \mathrm{s}_{-}^{-}$ & $\mathrm{t}-$ & b- & $\mathrm{k}-$ \\
\hline$a$ & $*$ & $*$ & $*$ & $*$ & $*$ & $\begin{array}{c}\text { ba- } \\
\text { 'bağlamak } \\
, \\
(\text { EDPT } \\
292 \mathbf{\Lambda}) \\
\end{array}$ & $\begin{array}{c}\text { ka- 'yı̆̆mak' } \\
\text { (EDPT } \\
578 \text { А ) }\end{array}$ \\
\hline $\begin{array}{l}b \\
i\end{array}$ & $\begin{array}{c}\text { ¿ 'orman' } \\
\text { (EDPT } 1 \\
\mathbf{A})\end{array}$ & $\begin{array}{l}y \imath \text { bk. } l \\
(\text { EDPT } \\
869 \text { ム) }\end{array}$ & * & $\begin{array}{c}\text { st- 'kirmak' } \\
\text { (EDPT } \\
872 \boldsymbol{\nabla})\end{array}$ & * & * & * \\
\hline $\begin{array}{l}u, \\
\ddot{u}\end{array}$ & $\begin{array}{c}\text { ü- } \\
\text { 'yükleme } \\
\text { k' }\end{array}$ & $\begin{array}{c}y \ddot{-}- \\
\text { ‘yüklem } \\
\text { ek’ } \\
\end{array}$ & * & $\begin{array}{c}\text { su- } \\
\text { 'sunmak' }\end{array}$ & $\begin{array}{c}\text { tü 'beden } \\
\text { k1lı' (EDPT } \\
433 \boldsymbol{\Delta})\end{array}$ & * & * \\
\hline
\end{tabular}


$\mathrm{J}(\mathrm{B})$

\begin{tabular}{|c|c|c|c|c|c|c|c|}
\hline & $\begin{array}{c}(\text { EDPT } \\
100 \wedge) \\
\end{array}$ & $\begin{array}{c}(\text { EDPT } \\
870 \Delta) \\
\end{array}$ & & $\begin{array}{l}(\text { EDPT } \\
782 \mathbf{\Delta})\end{array}$ & & & \\
\hline $\begin{array}{l}0, \\
\ddot{o}\end{array}$ & $*$ & $\begin{array}{l}\text { ?yo- } \\
\text { 'yok' }\end{array}$ & $*$ & $\begin{array}{c}\text { so 'zincir, } \\
\text { kilit' (EDPT } \\
781 \Delta)\end{array}$ & $\begin{array}{c}\text { to- } \\
\text { 'kapamak, } \\
\text { engellemek' } \\
\text { (EDPT } \\
434 \mathbf{\nabla}) \\
\\
\text { to- 'dolmak, } \\
\text { doldurulma } \\
\text { k' } \\
(\text { EDPT } \\
451 \mathbf{\Lambda})\end{array}$ & $*$ & $\begin{array}{c}\text { ?ko- } \\
\text { 'komak' } \\
\text { (EDPT } \\
578 \boldsymbol{\nabla} \text { ) }\end{array}$ \\
\hline $\begin{array}{c}a b, \\
e b \\
b \sim p\end{array}$ & $*$ & $\begin{array}{c}y a b- \\
\text { 'ylkmak } \\
\text { ' } \\
\text { bozmak' } \\
(\text { EDPT } \\
555 \mathbf{\nabla} \text { ) }\end{array}$ & $\begin{array}{c}\text { çap- } \\
\text { 'vurmak, } \\
\text { koşmak' } \\
\text { (EDPT } \\
394 \mathbf{\nabla} \text { ) } \\
\\
\text { çabak1 } \\
\text { (?çapak) } \\
\text { 'çapak' } \\
\text { (EDPT } \\
395 \text { ム) }\end{array}$ & $\begin{array}{c}\text { sap- } \\
\text { 'birleştirme } \\
\mathrm{k} \\
(\text { EDPT } \\
784 \mathbf{\Lambda}) \\
\\
\text { sep- } \\
\text { 'donatmak, } \\
\text { süslemek' } \\
\text { (EDPT } \\
784 \mathbf{\Lambda}) \\
\\
\text { ?sabı- } \\
\text { savurmak, } \\
\text { kuyruk } \\
\text { sallamak' } \\
\text { (EDPT } \\
\text { 785 } \mathbf{\nabla})\end{array}$ & $\begin{array}{c}\text { tap } \\
\text { 'yeterlilik, } \\
\text { tamlı' } \\
\text { (EDPT } \\
434 \mathbf{\Lambda}) \\
\\
\text { tap1- } \\
\text { 'yetmek, } \\
\text { yeterli } \\
\text { olmak; } \\
\text { hizmet } \\
\text { etmek; } \\
\text { ibadet } \\
\text { etmek' } \\
\text { (EDPT } \\
\text { 435 } \mathbf{\Lambda}) \\
\text { taban } \\
\text { 'taban' } \\
\text { (EDPT } \\
441 \mathbf{\nabla}) \\
\text { tabr- tebri- } \\
\text { 'sıçramak, } \\
\text { ziplamak, } \\
\text { atlayıp } \\
\text { ziplamak' } \\
\text { (EDPT } \\
443 \mathbf{\Delta} \text { ) }\end{array}$ & * & $\begin{array}{c}\text { kab 'kap, } \\
\text { deri çanta' } \\
\text { EDPT } \\
578 \mathbf{\Delta} \text { ) } \\
\text { kaba 'kaba, } \\
\text { şişkin' } \\
\text { (EDPT } \\
580 \mathbf{\Delta}) \\
\text { kebe 'gebe' } \\
\text { (EDPT } \\
687 \mathbf{\Lambda}) \\
\text { keber- } \\
\text { 'gebermek' } \\
\text { (EDPT } \\
691 \mathbf{\nabla})\end{array}$ \\
\hline
\end{tabular}




\begin{tabular}{|c|c|c|c|c|c|c|c|}
\hline & & & & & $\begin{array}{c}\text { tep- } \\
\text { 'vurmak' } \\
(\text { EDPT } \\
435 \mathbf{\nabla}) \\
\end{array}$ & & \\
\hline $\begin{array}{l}i b, \\
i b \\
b \sim p\end{array}$ & $\begin{array}{c}i p \text { bk. yıp } \\
(\mathrm{EDPT} \\
4 \mathbf{\Delta})\end{array}$ & $\begin{array}{l}\text { yip: 'ip, } \\
\text { sicim' } \\
\text { bk. } \\
\text { uruk, } \\
\text { yip, ip } \\
\text { (EDPT } \\
870 \text { ム) } \\
\text { yipke: } \\
\text { 'ip, } \\
\text { iplik' } \\
\text { (EDPT } \\
875 \mathbf{\Lambda} \text { ) }\end{array}$ & $\begin{array}{c}\text { çıban bk. } \\
\text { çıbıkan } \\
\text { (EDPT } \\
397 \mathbf{\Delta}) \\
\text { çıbıkan } \\
\text { 'hünnap; } \\
\text { çıan, } \\
\text { yara, } \\
\text { iltihap' } \\
\text { (EDPT } \\
396 \mathbf{\nabla}) \\
\\
\text { çıbık } \\
\text { 'çubuk' } \\
\text { (EDPT } \\
395 \mathbf{\Delta})\end{array}$ & $*$ & * & $\bar{*}$ & $\begin{array}{c}\text { kıp bk. kap } \\
\text { (EDPT } \\
579 \Delta \text { ) }\end{array}$ \\
\hline $\begin{array}{l}\text { ub, } \\
\ddot{u b} \\
\text { brp }\end{array}$ & $*$ & $*$ & $\begin{array}{c}\text { ?çübek } \\
\text { 'erkeklik } \\
\text { organı' } \\
\text { (EDPT } \\
396 \mathbf{\Delta}) \\
\\
\text { çupan 'köy } \\
\text { başçısı' } \\
\text { (EDPT } \\
397 \mathbf{\Delta})\end{array}$ & $\begin{array}{c}\text { subl 'söbü, } \\
\text { sivri' } \\
(\text { EDPT } \\
784 \mathbf{\Lambda}) \\
\\
\text { subl- } \\
\text { 'sivrilmek' } \\
(\text { EDPT } \\
784 \mathbf{\Lambda})\end{array}$ & $\begin{array}{c}\text { tüb 'dip, } \\
\text { kök' } \\
\text { (EDPT } \\
434 \mathbf{\nabla}) \\
\\
\text { tupul- } \\
\text { 'delinmek' } \\
\text { delinmek' } \\
\text { (EDPT } \\
440 \mathbf{\nabla})\end{array}$ & * & $\begin{array}{c}\text { kübi- } \\
\text { 'kabaca } \\
\text { dikmek' } \\
\text { (EDPT } \\
688 \mathbf{\Delta}) \\
\\
\text { küp 'küp, } \\
\text { çömlek' } \\
\text { (EDPT } \\
687 \mathbf{\Delta})\end{array}$ \\
\hline $\begin{array}{l}\text { ob, } \\
\ddot{o b} \\
b \sim p\end{array}$ & $\begin{array}{c}\text { ?oba 'oba, } \\
\text { geniş } \\
\text { aile, boy' } \\
\text { (EDPT } \\
5 \mathbf{\Delta} \text { ) } \\
\text { op- 'içine } \\
\text { çekmek, } \\
\text { yutmak' } \\
\text { (EDPT } \\
4 \mathbf{\nabla} \text { ) } \\
\text { opra- } \\
\text { 'yipranm }\end{array}$ & $*$ & $\begin{array}{c}\text { çöb ‘tortu, } \\
\text { çökelti’ } \\
\text { (EDPT } \\
394 \text { ム) }\end{array}$ & $\begin{array}{c}\text { bk. subl ve } \\
\text { subl- }\end{array}$ & $\begin{array}{c}\text { töp 'lapa, } \\
\text { bulamaç' } \\
\text { (EDPT } \\
434 \mathbf{\Lambda} \text { ) } \\
\text { töpü 'tepe, } \\
\text { doruk' } \\
\text { (EDPT } \\
436 \mathbf{\Lambda}) \\
\text { tob 'top' } \\
\text { (EDPT } \\
434 \mathbf{\Lambda})\end{array}$ & $*$ & $\begin{array}{c}\text { kop- } \\
\text { 'kopmak; } \\
\text { çlkmak, } \\
\text { yükselmek' } \\
\text { (EDPT } \\
580 \text { ム) } \\
\text { kop:köp } \\
\text { 'çok, hep, } \\
\text { bütün' } \\
\text { (EDPT } \\
579 \text { М) }\end{array}$ \\
\hline
\end{tabular}




\begin{tabular}{|c|c|c|c|c|c|c|c|}
\hline & $\begin{array}{c}\text { ak, } \\
\text { eskimek' } \\
(\text { EDPT } \\
14 \mathbf{\nabla}) \\
\\
\text { öp- } \\
\text { 'öpmek' } \\
(\text { EDPT } \\
5 \mathbf{\Lambda})\end{array}$ & & & & $\begin{array}{c}\text { top1- } \\
\text { 'toplamak' } \\
\text { (EDPT } \\
434 \mathbf{\Lambda} \text { ) } \\
\text { topra- } \\
\text { 'kurumak, } \\
\text { kuruyup } \\
\text { solmak' bk. } \\
\text { toprak } \\
\text { (EDPT } \\
444 \mathbf{\nabla} \text { ) }\end{array}$ & & $\begin{array}{c}\text { köp- } \\
\text { 'köpürmek, } \\
\text { çoğalmak' } \\
\text { (EDPT } \\
687 \text { М) }\end{array}$ \\
\hline $\begin{array}{l}a c ̧, \\
e c ̧\end{array}$ & $\begin{array}{c}\text { aç1- } \\
\text { 'açmak; } \\
\text { çözmek, } \\
\text { arıtmak' } \\
(\text { EDPT } \\
18 \nabla \text { ) }\end{array}$ & $*$ & $\begin{array}{c}\text { çaçır bk. } \\
\text { çatır }\end{array}$ & $\begin{array}{c}\text { saç- } \\
\text { 'saçmak, } \\
\text { serpmek; } \\
\text { yaymak' } \\
\text { (EDPT } \\
794 \mathbf{\Lambda} \text { ) } \\
\\
\text { ?saç1 'saç, } \\
\text { kıl' } \\
\text { (EDPT } \\
794 \mathbf{\Lambda} \text { ) } \\
\text { saç2 } \\
\text { 'demirden } \\
\text { yapılmış } \\
\text { yayvan kap' } \\
\text { seç- } \\
\text { 'seçmek, } \\
\text { ayırmak' } \\
\text { (EDPT } \\
\text { 794 } \mathbf{\nabla} \text { ) }\end{array}$ & * & $\begin{array}{c}\text { beçkem } \\
\text { 'savaş } \\
\text { günü } \\
\text { savaşçını } \\
\text { n giydiği, } \\
\text { ipek veya } \\
\text { öküz } \\
\text { kuyruğun } \\
\text { dan } \\
\text { yapılan } \\
\text { topuz, } \\
\text { tuğ; } \\
\text { perçem' } \\
\text { (EDPT } \\
\text { 295 } \mathbf{\Delta} \text { ) bk. } \\
\text { perçem } \\
\\
\text { beçküm } \\
\text { 'sofa, } \\
\text { hayat, } \\
\text { evin } \\
\text { önündeki } \\
\text { çıkıntı' } \\
\text { (EDPT } \\
295 \mathbf{\Delta} \text { ) } \\
\end{array}$ & $\begin{array}{l}\text { kaç-'kaçmak } \\
\text {, ayrilıp } \\
\text { gitmek' } \\
\text { (EDPT } \\
589 \boldsymbol{\nabla} \text { ) } \\
\text { keç- 'aşmak' } \\
\text { (EDPT } \\
693 \text { М ) }\end{array}$ \\
\hline $\begin{array}{l}\text { iç, } \\
\text { iç }\end{array}$ & $\begin{array}{c}\text { iç 'iç' } \\
(\mathrm{EDPT} \\
17 \mathbf{\Delta}) \\
\\
\text { iç- } \\
\text { 'içmek' }\end{array}$ & yiç bk. iç & $\begin{array}{c}\text { çı̧alak } \\
\text { 'küçük } \\
\text { parmak' } \\
\text { (EDPT } \\
401 \mathbf{\Delta})\end{array}$ & $\begin{array}{c}\text { sıç- } \\
\text { 'bagırsak } \\
\text { boşaltmak, } \\
\text { siçmak' } \\
\text { (EDPT } \\
795 \mathbf{\nabla})\end{array}$ & $\begin{array}{c}\text { tıçgan bk. } \\
\text { şı̧̧gan } \\
\text { (EDPT 796) }\end{array}$ & $\begin{array}{c}\text { bıç- } \\
\text { /biç-'biçm } \\
\text { ek, } \\
\text { kesmek' } \\
\text { (EDPT } \\
292 \nabla \text { ) }\end{array}$ & $\begin{array}{c}\text { kıçtın bk. } \\
\text { sıçgan } \\
\text { (EDPT 590) } \\
\text { ?kiçig; } \\
\text { 'küçük; }\end{array}$ \\
\hline
\end{tabular}


$\mathrm{J}(\mathrm{B})$

\begin{tabular}{|c|c|c|c|c|c|c|c|}
\hline & $\begin{array}{c}\text { (EDPT } \\
19 \mathbf{\Lambda}) \\
\text { ıçıı- } \\
\text { 'salmak, } \\
\text { bırakmak } \\
; \\
\text { kaybolma } \\
\text { k, } \\
\text { ortadan } \\
\text { kalkmak; } \\
\text { kaçırmak } \\
\text { ' (EDPT } \\
\text { 23 } \mathbf{\nabla} \text { ) bk. } \\
\text { ıskan-, } \\
\text { ıskala- }\end{array}$ & & & $\begin{array}{c}\text { sıçgan } \\
\text { ‘sıçan' bk. } \\
\text { çı̧gan, } \\
\text { tıçgan, } \\
\text { tışgan } \\
\text { (EDPT } \\
796 \mathbf{\Delta}) \\
\text { ?sıçı 'dört } \\
\text { taraf' } \\
\text { (EDPT } \\
795 \mathbf{\Delta})\end{array}$ & & & $\begin{array}{c}\text { enik, köpek } \\
\text { yavrusu' } \\
\text { (EDPT } \\
696 \text { \) }\end{array}$ \\
\hline $\begin{array}{l}u c ̧, \\
\ddot{u} c ̧\end{array}$ & $\begin{array}{c}\text { uç 'uç, } \\
\text { son, kıy' } \\
\text { (EDPT } \\
17 \mathbf{\Delta}) \\
\text { uç-'uçma } \\
\text { k; ölmek, } \\
\text { yitmek' } \\
\text { (EDPT } \\
19 \mathbf{\nabla}) \\
\\
\text { uçuk1 } \\
\text { 'tahıl } \\
\text { kabuğu, } \\
\text { kepek; } \\
\text { ateş } \\
\text { lekesi, } \\
\text { siğil, } \\
\text { uçuk; } \\
\text { gözde } \\
\text { çıkan } \\
\text { arpacık' } \\
\text { (EDPT } \\
22 \mathbf{\nabla})\end{array}$ & $*$ & $*$ & $\begin{array}{l}\text { suç 'sıyrık; } \\
\text { suç, kusur' } \\
\text { (EDPT } \\
794 \text { V) bk. } \\
\text { sıd- }\end{array}$ & $*$ & $\begin{array}{c}\text { buçgak } \\
\text { 'bucak, } \\
\text { köşe' } \\
\text { (EDPT } \\
294 \mathbf{\Delta} \text { ) }\end{array}$ & $\begin{array}{c}\text { ?kuç- } \\
\text { 'kucaklama } \\
\text { k' } \\
(\text { EDPT } \\
590 \mathbf{\Delta})\end{array}$ \\
\hline $\begin{array}{l}\text { oç, } \\
\text { öç }\end{array}$ & F* & ** & $\begin{array}{c}\text { ?çoçuk } \\
\text { 'domuz } \\
\text { yavrusu; } \\
\text { çocuk' }\end{array}$ & ** & ** & ** & $\begin{array}{c}\text { köç1 'göç' } \\
\text { (EDPT } \\
693 \text { ム) }\end{array}$ \\
\hline
\end{tabular}




\begin{tabular}{|c|c|c|c|c|c|c|c|}
\hline & & & $\begin{array}{l}(\mathrm{EDPT} \\
400 \mathbf{\Delta})\end{array}$ & & & & $\begin{array}{c}\text { köç- } \\
\text { 'göçmek, } \\
\text { taşınmak; } \\
\text { ölmek' } \\
\text { (EDPT } \\
694 \mathbf{\nabla}) \\
\\
\text { köçük 'göt, } \\
\text { kıç' } \\
\text { (EDPT } \\
697 \mathbf{\Lambda})\end{array}$ \\
\hline $\begin{array}{l}a k, \\
e k \\
k \sim g\end{array}$ & $\begin{array}{c}\text { ag- } \\
\text { ‘ağmak, } \\
\text { yükselme } \\
\text { k' } \\
(\text { EDPT } \\
76 \mathbf{\Delta})\end{array}$ & $\begin{array}{c}\text { yak yuk } \\
\text { 'yemek } \\
\text { artı̆̆1' } \\
\text { (EDPT } \\
895 \mathbf{\nabla}) \\
\\
\text { yak1- } \\
\text { 'ovalam } \\
\text { ak, } \\
\text { sürtmek } \\
\text {, } \\
\text { (EDPT } \\
896 \mathbf{\Lambda}) \\
\\
\text { yagan } \\
\text { 'fil' } \\
\text { (EDPT } \\
904 \mathbf{\Delta})\end{array}$ & $\begin{array}{c}\text { çak- } \\
\text { 'çakmak' } \\
(\text { EDPT } \\
405 \mathbf{\Lambda}) \\
\\
\text { çek2- } \\
\text { 'çekmek' } \\
(\text { EDPT } \\
413 \mathbf{\Lambda}) \\
\\
\text { çek2- } \\
\text { 'çekiliş' } \\
(\text { EDPT } \\
413 \mathbf{\Lambda}) \\
\\
\text { cagan bk. } \\
\text { yagan }\end{array}$ & $\begin{array}{c}\text { sékri- } \\
\text { 'sekmek, } \\
\text { siçramak' } \\
\text { (EDPT } \\
822 \mathbf{\Delta})\end{array}$ & $\begin{array}{c}\text { tak- } \\
\text { 'takmak' } \\
(\mathrm{EDPT} \\
464 \mathbf{\Lambda}) \\
\\
\text { tag1 'dağ' } \\
(\text { EDPT } \\
463 \mathbf{\Lambda}) \\
\\
\text { tagar 'geniş } \\
\text { kap, torba' } \\
\text { (EPTD } \\
471 \mathbf{\Lambda})\end{array}$ & $\begin{array}{c}\text { bag ‘bağ, } \\
\text { örgü’ } \\
\text { (EDPT } \\
310 \mathbf{\Lambda} \text { ) } \\
\text { ?bagır } \\
\text { 'bağır, } \\
\text { böğür; } \\
\text { ciğer' } \\
\text { (EDPT } \\
317 \mathbf{\Lambda} \text { ) }\end{array}$ & $\begin{array}{c}\text { kak- } \\
\text { 'çakmak, } \\
\text { vurmak' } \\
\text { (EDPT } \\
609 \mathbf{\nabla}) \\
\\
\text { kakaç 'kir' } \\
(\text { EDPT } \\
610 \nabla)\end{array}$ \\
\hline $\begin{array}{l}\imath k \\
i k \\
k \sim g\end{array}$ & $\begin{array}{c}\text { ıg- } \\
\text { 'yığmak, } \\
\text { pıhtılaşm } \\
\text { ak' } \\
(\text { EDPT } \\
77 \mathbf{V}) \\
\\
\text { ıgaç } \\
\text { 'orman' } \\
\text { (EDPT } \\
79 \mathbf{\Delta})\end{array}$ & $\begin{array}{c}\text { ylk- } \\
\text { 'yıkmak } \\
, \\
\text { (EDPT } \\
897 \boldsymbol{\nabla} \text { ) } \\
\\
\text { yıg- } \\
\text { 'yığmak } \\
, \\
\text { (EDPT } \\
897 \mathbf{\nabla} \text { ) } \\
\\
\text { yıgaç } \\
\text { 'orman' }\end{array}$ & $\begin{array}{c}\text { çık 'tam, } \\
\text { bütün; } \\
\text { tamamen, } \\
\text { bütünüyle } \\
\text { '(EDPT } \\
404 \mathbf{\Lambda}) \\
\\
\text { çık- } \\
\text { 'çıkmak' } \\
\text { (EDPT } \\
405 \mathbf{\nabla}) \\
\text { çıg- } \\
\text { 'yığmak' }\end{array}$ & 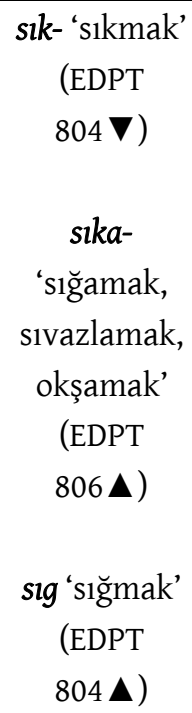 & $\begin{array}{c}\text { ttk- } \\
\text { 'doldurmak' } \\
\text { (EDPT } \\
465 \mathbf{\Lambda}) \\
\text { tıg- } \\
\text { 'keskinliğin } \\
\text { i yitirmek; } \\
\text { örtüp } \\
\text { saklamak; } \\
\text { boyun } \\
\text { eğmek,' } \\
\text { (EDPT } \\
465 \mathbf{\nabla})\end{array}$ & $\begin{array}{c}\text { ?bık- } \\
\text { 'bıkmak' } \\
\text { bıkın } \\
\text { 'kalça' } \\
\text { (EDPT } \\
316 \mathbf{\Lambda}) \\
\\
\text { bıgrıg } \\
\text { 'tulum, } \\
\text { torba' } \\
\text { (EDPT } \\
318 \mathbf{\Delta})\end{array}$ & $\begin{array}{c}\text { kik-:'birbiri } \\
\text { ne sürtmek, } \\
\text { bilemek' bk. } \\
\text { kiksür- } \\
\text { (EDPT } \\
710 \mathbf{\Delta} \text { ) } \\
\text { kıglat-'gübr } \\
\text { eletmek' } \\
\text { bk. kıg } \\
\text { 'gübre' } \\
\text { (EDPT } \\
610 \mathbf{\Delta})\end{array}$ \\
\hline
\end{tabular}


J(৫)

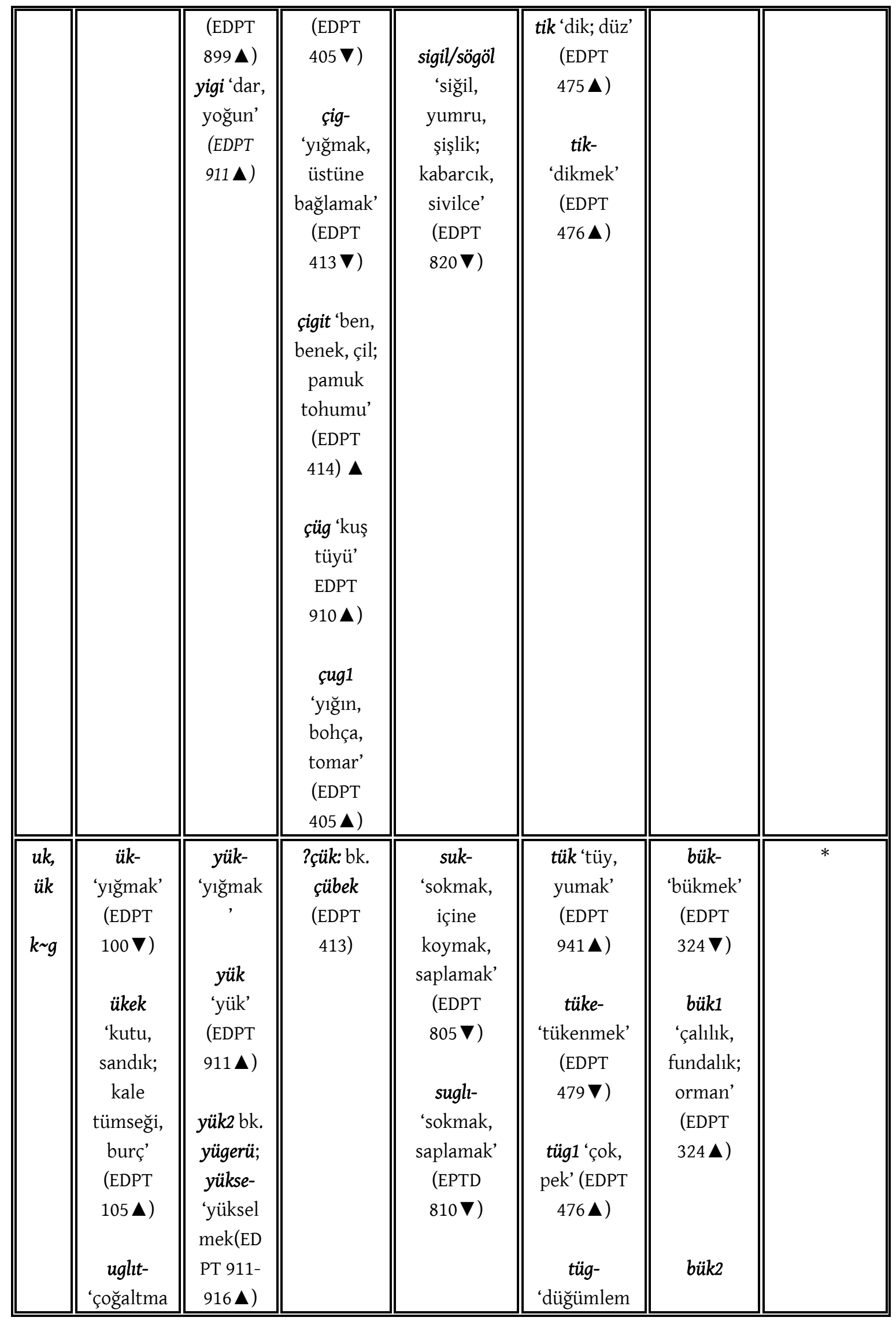




\begin{tabular}{|c|c|c|c|c|c|c|c|}
\hline & $\begin{array}{l}\text { k' bk. }^{\prime} \\
\text { öklit- } \\
(\text { EDPT } \\
86 \triangle)\end{array}$ & 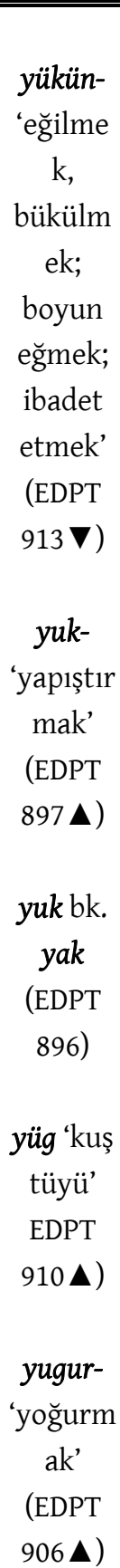 & & $\begin{array}{c}\text { sug-/sugur- } \\
\text { 'emmek; } \\
\text { çıkarmak' } \\
\text { (EDPT } \\
805 \mathbf{\nabla}) \\
\\
\text { sugur } \\
\text { 'bobak, dag } \\
\text { sıçanı; oklu } \\
\text { kirpi; } \\
\text { samur' } \\
\text { (EDPT } \\
815 \mathbf{A} \text { ) }\end{array}$ & $\begin{array}{c}\mathrm{e}, \\
\text { bağlamak' } \\
\text { düy-(EDPT } \\
477 \mathbf{\Delta})\end{array}$ & $\begin{array}{c}\text { 'ev; evin } \\
\text { bir köşesi' } \\
\text { (EDPT } \\
324 \mathbf{\Lambda}) \\
\text { ?büktel } \\
\text { 'olgun; } \\
\text { sirtı geniş } \\
\text { at' (EDPT } \\
325 \mathbf{\Lambda}) \\
\\
\text { bugra- } \\
\text { 'doğrama } \\
\text { k, dilmek, } \\
\text { oymak, } \\
\text { çentmek' } \\
\text { (EDPT } \\
\text { 318 } \mathbf{\nabla})\end{array}$ & \\
\hline $\begin{array}{l}\text { ok, } \\
\text { ök } \\
k \sim g\end{array}$ & $\begin{array}{c}\text { og- } \\
\text { 'ovmak' } \\
\text { (EDPT } \\
77 \mathbf{\Lambda}) \\
\\
\text { ?ög- } \\
\text { 'yüceltm } \\
\text { ek' } \\
(\text { EDPT } \\
100 \mathbf{\Delta})\end{array}$ & $\begin{array}{c}\text { yok } \\
\text { 'yok' } \\
\text { (EDPT } \\
895 \mathbf{\nabla}) \\
\\
\text { yok2'yü } \\
\text { ksek } \\
\text { yer' } \\
\text { bk. } \\
\text { yokaru }\end{array}$ & $\begin{array}{c}\text { çok- } \\
\text { 'saldırma } \\
\text { k, } \\
\text { vurmak' } \\
\text { (EDPT } \\
406 \nabla \text { ) } \\
\text { ?çok 'çok' }\end{array}$ & $\begin{array}{c}\text { sok- } \\
\text { 'sokmak, } \\
\text { delmek' } \\
\text { (EDPT } \\
805 \nabla \text { ) } \\
\text { sök1- } \\
\text { ‘sökmek, } \\
\text { çıkarmak' }\end{array}$ & $\begin{array}{c}\text { tok1 'dolu' } \\
\text { (EDPT } \\
464 \mathbf{\Lambda}) \\
\text { tokl- } \\
\text { 'vurmak' } \\
(\mathrm{EDPT} \\
467 \mathbf{\nabla}) \\
\\
\text { tök- }\end{array}$ & $\begin{array}{c}\text { bok } \\
\text { 'bağdaş } \\
\text { kurmak' } \\
\text { (EDPT } \\
311 \mathbf{\Lambda}) \\
\text { bokun } \\
\text { 'yığın; } \\
\text { halk, kara } \\
\text { budun' }\end{array}$ & $\begin{array}{c}\text { kok kog } \\
\text { 'toz, kül' } \\
(\text { EDPT } \\
609 \mathbf{\Delta}) \\
\\
\text { kögen } \\
\text { 'ilmik, } \\
\text { kement, } \\
\text { kuşak' }\end{array}$ \\
\hline
\end{tabular}




\begin{tabular}{|c|c|c|c|c|c|c|c|}
\hline & $\begin{array}{c}\text { ögi- } \\
\text { ‘öğütmek } \\
\text {; ezmek, } \\
\text { toz } \\
\text { haline } \\
\text { getirmek’ } \\
\text { (EDPT } \\
101 \mathbf{\nabla})\end{array}$ & $\begin{array}{c}(\text { EDPT } \\
896 \mathbf{\Lambda}) \\
\text { yogun } \\
\text { 'yoğun' } \\
\text { (EPTD } \\
904 \mathbf{\Lambda}) \\
\\
\text { yogrn } \\
\text { 'geniş } \\
\text { ve derin } \\
\text { kap' } \\
\text { (EDPT } \\
905 \mathbf{\Lambda} \text { ) } \\
\text { yögüt- } \\
\text { bk. ögit- } \\
\text { (EDPT } \\
\text { 912 } \mathbf{\Delta} \text { ) }\end{array}$ & $\begin{array}{c}\text { çök- } \\
\text { 'diz } \\
\text { çökmek } \\
\text { eğilmek; } \\
\text { azalmak' } \\
\text { (EDPT } \\
413 \mathbf{\nabla} \text { ) } \\
\text { çögen } \\
\text { 'sopa, ucu } \\
\text { egri } \\
\text { degnek' } \\
\text { (EDPT } \\
416 \mathbf{\Delta} \text { ) }\end{array}$ & 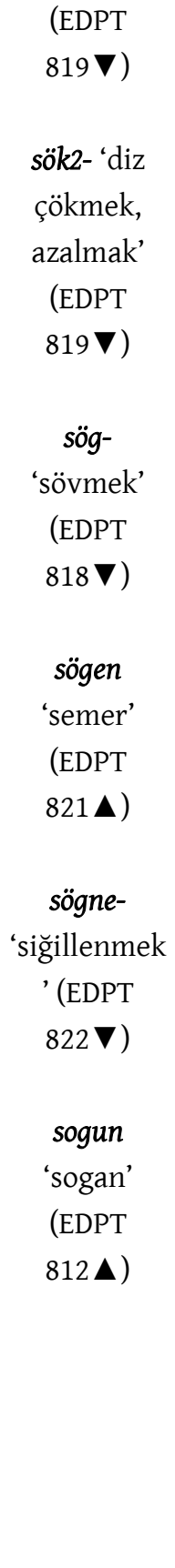 & $\begin{array}{l}\text { 'dökmek, } \\
\text { doldurmak' } \\
\text { (EDPT } \\
477 \mathbf{\Lambda}) \\
\text { tog 'toz' } \\
\text { (EDPT } \\
609 \mathbf{\Delta}) \\
\text { tog2 'tıkall, } \\
\text { kapalı' } \\
\text { togra- } \\
\text { 'doğramak, } \\
\text { kesmek, } \\
\text { parçalamak } \\
\text { '(EDPT } \\
472 \mathbf{\nabla}) \\
\text { tög- } \\
\text { 'dövmek, } \\
\text { ezmek' } \\
\text { (EDPT } \\
477 \mathbf{\nabla})\end{array}$ & $\begin{array}{c}\text { (EDPT } \\
316 \mathbf{\Delta}) \\
\text { bok1 } \\
\text { bokdam } \\
\text { 'küf } \\
\text { (EDPT } \\
\text { 312 } \mathbf{\Delta}) \\
\\
\text { bog } \\
\text { 'bohça, } \\
\text { çııı, } \\
\text { tomar' } \\
\text { (EDPT } \\
\text { 311 } \mathbf{\Delta} \text { ) } \\
\text { bog } \\
\text { 'boğmak, } \\
\text { boğazlam } \\
\text { ak' (EDPT } \\
\text { 311 } \mathbf{\nabla} \text { ) } \\
\text { bogrul } \\
\text { 'tulum, } \\
\text { torba' } \\
\text { (EDPT } \\
\text { 318 } \mathbf{\Delta} \text { ) } \\
\text { 'toplamak } \\
\text { bir araya } \\
\text { getirmek' } \\
\text { (EDPT } \\
\text { 324 } \mathbf{\Delta} \text { ) }\end{array}$ & $\begin{array}{c}(\mathrm{EDPT} \\
712 \mathbf{\Delta}) \\
\\
\text { kögür- } \\
\text { 'girdirmek, } \\
\text { sokmak, } \\
\text { içeri almak' } \\
\text { bk. kigür- } \\
\text { (EDPT } \\
713 \mathbf{\Lambda})\end{array}$ \\
\hline & & & & & & & \\
\hline $\begin{array}{l}a b \\
e l\end{array}$ & $*$ & $*$ & $\begin{array}{c}\text { çal- } \\
\text { ‘vurmak, } \\
\text { çarpmak' } \\
\text { (EDPT } \\
417 \boldsymbol{\nabla}) \\
\text { çalgay 'kaz } \\
\text { tüyü, } \\
\text { kuşun ön }\end{array}$ & $\begin{array}{c}\text { sal- 'salmak, } \\
\text { hareket } \\
\text { ettirmek' } \\
(\text { EDPT } \\
824 \mathbf{\Lambda})\end{array}$ & $*$ & * & $\begin{array}{c}\text { kal- } \\
\text { 'kalmak; } \\
\text { durmak' } \\
\text { (EDPT } \\
615 \nabla \text { ) } \\
\\
\text { kalbuz } \\
\text { 'yı̆̆ın, } \\
\text { küme; }\end{array}$ \\
\hline
\end{tabular}




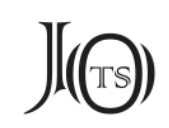

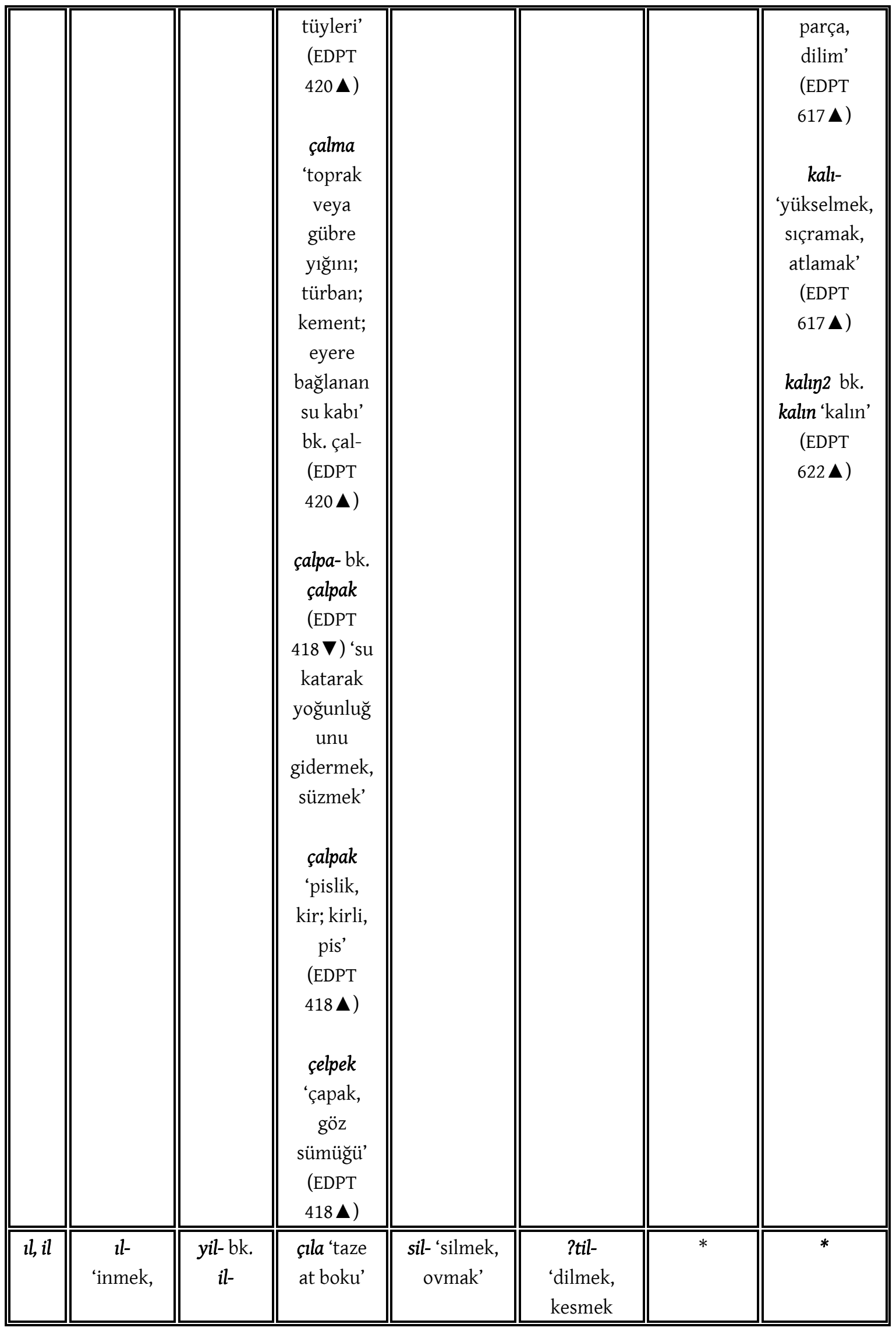


I(⿴)

\begin{tabular}{|c|c|c|c|c|c|c|c|}
\hline & $\begin{array}{c}\text { çökmek, } \\
\text { alçalmak' } \\
\text { (EDPT } \\
125 \mathbf{\nabla}) \\
\text { il- } \\
\text { 'tutmak, } \\
\text { yakalama } \\
\text { k; } \\
\text { ellemek' } \\
\text { (EDPT } \\
\text { 125 } \mathbf{\Delta}) \\
\\
\text { ?ilk 'ilk, } \\
\text { birinci; } \\
\text { önceki' } \\
\text { (EDPT } \\
140 \mathbf{\Delta} \text { ) }\end{array}$ & 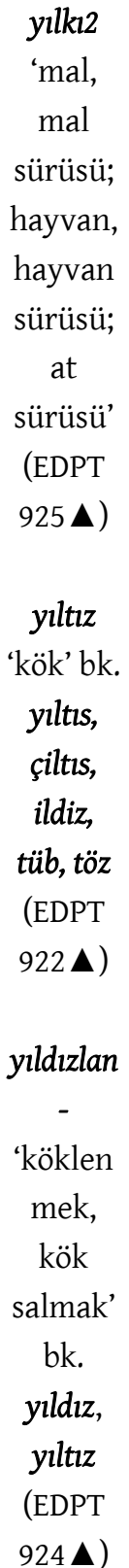 & $\begin{array}{c}\text { (EDPT } \\
418 \mathbf{\Lambda}) \\
\text { ?çil 'çil, } \\
\text { leke; sırt; } \\
\text { sınır' } \\
\text { (EDPT } \\
417 \mathbf{\Lambda})\end{array}$ & $\begin{array}{c}(\text { EDPT } \\
824 \mathbf{\Lambda}) \\
\text { silk- } \\
\text { 'silkmek' } \\
(\text { EDPT } \\
826 \mathbf{V})\end{array}$ & $\begin{array}{l}\text { (EDPT } \\
490 \boldsymbol{\nabla})\end{array}$ & & \\
\hline $\begin{array}{l}u l \\
u ̈ l\end{array}$ & $\begin{array}{c}\text { ul 'alt, } \\
\text { dip, } \\
\text { temel' } \\
\text { (EDPT } \\
124 \mathbf{\Lambda} \text { ) } \\
\text { ula 'sınır, } \\
\text { sinır taş' } \\
\text { (EDPT } \\
126 \mathbf{\Delta})\end{array}$ & $\begin{array}{c}\text { yul } \\
\text { 'kaynak' } \\
\text { (EPTD } \\
917 \text { ム) } \\
\\
\text { yul- } \\
\text { yolmak, } \\
\text { çıarma } \\
\text { k' } \\
\text { (EDPT } \\
932 \mathbf{\nabla})\end{array}$ & $\begin{array}{c}\text { çulıman } \\
\text { 'su } \\
\text { birikintisi' } \\
(\text { EDPT } \\
420 \mathbf{\Lambda}) \\
\\
\text { çülük- } \\
\text { 'yolukmak } \\
\text {, } \\
\text { yipranma } \\
\text { k' }\end{array}$ & $*$ & $\begin{array}{c}\text { tul- } \\
\text { 'çatmak, } \\
\text { çarpmak' } \\
\text { (EDPT } \\
491 \mathbf{\nabla} \text { ) } \\
\\
\text { tuluk } \\
\text { 'tulum, içki } \\
\text { tulumu' } \\
\text { (EPTD } \\
495 \mathbf{\Lambda})\end{array}$ & $\begin{array}{l}\text { ?bulak1 } \\
\text { 'bulak, } \\
\text { göze' } \\
\text { (EDPT } \\
336 \mathbf{\Delta})\end{array}$ & $\begin{array}{c}\text { kül 'kül' } \\
\text { (EDPT } \\
715 \Delta \text { ) }\end{array}$ \\
\hline
\end{tabular}


J(ङ)

\begin{tabular}{|c|c|c|c|c|c|c|c|}
\hline & $\begin{array}{c}\text { ula- } \\
\text { 'birleştir } \\
\text { mek; } \\
\text { eklemek' } \\
\text { (EDPT } \\
126 \mathbf{\Delta} \text { ) } \\
\\
\text { üle- } \\
\text { 'bölmek; } \\
\text { üleştirme } \\
\text { k' } \\
\text { (EDPT } \\
127 \mathbf{V})\end{array}$ & $\begin{array}{c}\text { yular } \\
\text { 'yular' } \\
(\text { EDPT } \\
932 \mathbf{\Delta}) \\
\\
\text { ?yüli- } \\
\text { 'tıraş } \\
\text { etmek' } \\
\text { (EDPT } \\
\text { 919 \) }\end{array}$ & $\begin{array}{c}\text { (EDPT } \\
420 \boldsymbol{\nabla}) \\
\text { çülik 'çöl' } \\
\text { (EDPT } \\
417 \mathbf{\Delta})\end{array}$ & & $\begin{array}{l}\text { tuluy 'zülüf; } \\
\text { saç umağı, } \\
\text { lüle' } \\
\text { (EDPT } \\
501 \mathbf{\Lambda})\end{array}$ & & \\
\hline $\begin{array}{l}\text { ol, } \\
\text { oll }\end{array}$ & $\begin{array}{c}\text { ?ol- } \\
\text { 'olmak' } \\
(\text { EDPT } \\
125 \mathbf{\Delta}) \\
\\
\text { oluk1 } \\
\text { 'ağaç } \\
\text { gövdesin } \\
\text { deki } \\
\text { delik' } \\
\text { (EDPT } \\
\text { 137 } \mathbf{\Delta}) \\
\text { oluk2 } \\
\text { 'atın } \\
\text { kürek } \\
\text { kemikleri } \\
\text { arasındak } \\
\text { i çukur' } \\
\text { (EDPT } \\
\text { 137 } \mathbf{\nabla}) \\
\\
\text { ?öl- } \\
\text { 'ölmek } \\
(\text { EDPT } \\
\text { 125 } \mathbf{\nabla}) \\
\end{array}$ & * & $\begin{array}{c}\text { çöl bk. } \\
\text { çülik }\end{array}$ & $\begin{array}{c}\text { sol- 'solmak' } \\
\text { (EDPT } \\
828 \boldsymbol{\nabla})\end{array}$ & $\begin{array}{c}\text { tol- } \\
\text { 'dolmak, } \\
\text { doldurulma } \\
\text { k' } \\
(\text { EDPT } \\
491 \mathbf{\Lambda}) \\
\\
\text { tola-bk. } \\
\text { tolga- } \\
\text { 'dolamak, } \\
\text { sarmak' } \\
\text { (EDPT } \\
492 \mathbf{\Delta})\end{array}$ & $\begin{array}{c}\text { bol 'bol; } \\
\text { çok' } \\
\text { (EDPT } \\
330 \mathbf{\Delta}) \\
\\
\text { bol- } \\
\text { 'olmak' } \\
(\text { EDPT } \\
331 \mathbf{\Lambda}) \\
\\
\text { böl- } \\
\text { 'bölmek' } \\
(E D P T \\
332 \mathbf{\nabla})\end{array}$ & $\begin{array}{c}\text { köl 'göl; } \\
\text { büyük su } \\
\text { kütlesi, } \\
\text { deniz' } \\
\text { (EDPT } \\
715 \mathbf{\Delta})\end{array}$ \\
\hline $\begin{array}{l}\text { am, } \\
\mathrm{em}\end{array}$ & $\begin{array}{c}e m- \\
\text { 'emmek, } \\
\text { içine } \\
\text { çekmek' }\end{array}$ & $\begin{array}{c}\text { yama- } \\
\text { 'yamam } \\
\text { ak' } \\
(\text { EDPT } \\
934 \mathbf{\nabla})\end{array}$ & * & $\begin{array}{c}\text { semiz } \\
\text { ‘semiz, } \\
\text { şişman' bk. } \\
\text { semri- }\end{array}$ & $\begin{array}{c}\text { tam1 } \\
\text { 'duvar, çatı' } \\
(\text { EDPT } \\
502 \mathbf{\Lambda})\end{array}$ & $\begin{array}{c}\text { bamuk } \\
\text { 'pamuk' } \\
\text { (EDPT } \\
345 \mathbf{\Lambda})\end{array}$ & $\begin{array}{c}\text { kem-? bk. } \\
\text { kemir- } \\
\text { 'kemirmek' } \\
(\text { EDPT } \\
721 \mathbf{\nabla})\end{array}$ \\
\hline
\end{tabular}


J((3)

\begin{tabular}{|c|c|c|c|c|c|c|c|}
\hline & $\begin{array}{c}\text { (EDPT } \\
155 \mathbf{\Lambda}) \\
\\
\text { emri- } \\
\text { 'kaşımak, } \\
\text { yıpratma } \\
\text { k, } \\
\text { aşındırm } \\
\text { ak, } \\
\text { bozmak' } \\
\text { (EDPT } \\
163 \mathbf{\nabla}) \\
\end{array}$ & $\begin{array}{c}\text { yamraş- } \\
\text { 'toplaş } \\
\text { mak' } \\
(\text { EDPT } \\
937 \mathbf{\Lambda} \text { ) }\end{array}$ & & $\begin{array}{l}(\mathrm{EDPT} \\
830 \boldsymbol{\Delta})\end{array}$ & & & $\begin{array}{c}\text { kama- } \\
\text { 'kamaşmak, } \\
\text { toplaşmak' } \\
(\text { EDPT } \\
625 \mathbf{\Delta})\end{array}$ \\
\hline $\begin{array}{l}\text { im, } \\
\text { im }\end{array}$ & $*$ & $*$ & $*$ & $\begin{array}{c}\text { şım ‘tam, } \\
\text { bütün' bk. } \\
\text { çı๊2 } \\
(\mathrm{EDPT} \\
424 \mathbf{\Lambda}) \\
\end{array}$ & $\begin{array}{c}\text { tim 'şarap } \\
\text { tulumu' } \\
(\text { EDPT } \\
503 \mathbf{\Delta})\end{array}$ & $*$ & $*$ \\
\hline $\begin{array}{l}\text { um, } \\
\ddot{u m}\end{array}$ & $*$ & $\begin{array}{c}\text { yum- } \\
\text { 'yumma } \\
\text { k, } \\
\text { kapama } \\
\text { k' } \\
\text { (EDPT } \\
934 \mathbf{\nabla}) \\
\\
\text { yumruk } \\
\text { bk. } \\
\text { yıdruk } \\
\text { (EDPT } \\
937 \mathbf{\Delta})\end{array}$ & $*$ & $*$ & 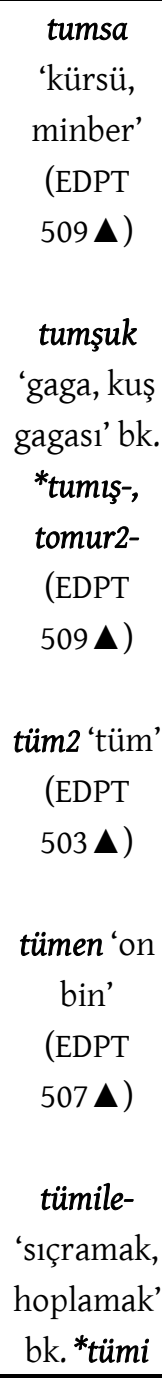 & $*$ & $\begin{array}{c}\text { kum 'kum' } \\
\text { (EDPT } \\
625 \Delta \text { ) }\end{array}$ \\
\hline
\end{tabular}




\begin{tabular}{|c|c|c|c|c|c|c|c|}
\hline & & & & & $\begin{array}{c}\text { (EDPT } \\
507 \mathbf{\Lambda}) \\
\\
\text { tümrüg } \\
\text { 'tambur, } \\
\text { davul' } \\
(\text { EDPT } \\
509 \mathbf{\Lambda}) \\
\end{array}$ & & \\
\hline $\begin{array}{l}\text { om, } \\
\text { öm }\end{array}$ & $\begin{array}{c}\text { om 'karın } \\
\text { şişkinliği' } \\
(\text { EDPT } \\
155 \Delta)\end{array}$ & $\begin{array}{c}\text { yomdar } \\
\text { 'toplan } \\
\text { mak, } \\
\text { birikme } \\
\text { k' } \\
(\text { EDPT } \\
935 \mathbf{\Delta})\end{array}$ & $\begin{array}{c}\text { çom:çöm } \\
\text { 'çömmek, } \\
\text { suya } \\
\text { dalmak' } \\
\text { (EDPT } \\
422 \mathbf{\nabla} \text { ) } \\
\\
\text { çömçe } \\
\text { 'kepçe' } \\
\text { (EDPT } \\
422 \mathbf{\Delta} \text { ) }\end{array}$ & * & $\begin{array}{c}\text { toma 'boza } \\
\text { kabının } \\
\text { tepesine } \\
\text { yükselen } \\
\text { köpük } \\
\text { kısmı' } \\
\text { (EDPT } \\
503 \mathbf{\Delta}) \\
\\
\text { tomur2- } \\
\text { 'yuvarlak } \\
\text { biçimli } \\
\text { kesmek, } \\
\text { kütük } \\
\text { halinde } \\
\text { kesmek' } \\
\text { (EDPT } \\
\text { 509 } \mathbf{\nabla} \text { ) }\end{array}$ & $*$ & $\begin{array}{c}\text { kom2 'dalga' } \\
\text { (EPTD } \\
625 \mathbf{\Delta}) \\
\text { kom- } \\
\text { 'dalgalanm } \\
\text { ak' } \\
\text { (EDPT } \\
625 \mathbf{\Delta}) \\
\\
\text { komı- } \\
\text { 'kabarmak, } \\
\text { şişmek; } \\
\text { özlemek, } \\
\text { hasret } \\
\text { çekmek; } \\
\text { canlanmak' } \\
\text { (EDPT } \\
626 \text { V) } \\
\text { köm- } \\
\text { 'gömmek' } \\
\text { (EDPT } \\
721 \mathbf{v}) \\
\text { kömür } \\
\text { 'kömür' bk. } \\
\text { köm- (EDPT } \\
723 \mathbf{\Delta})\end{array}$ \\
\hline $\begin{array}{c}a n, \\
e n \\
n \sim y\end{array}$ & $\begin{array}{c}\text { én- } \\
\text { 'inmek, } \\
\text { yukarıda } \\
\text { n aşağıya } \\
\text { gitmek' }\end{array}$ & $\begin{array}{c}\text { yan4- } \\
\text { ‘saçmak } \\
\text {, } \\
\text { dağıttma } \\
\text { k, }\end{array}$ & $*$ & $\begin{array}{c}\text { say 'kuş } \\
\text { boku' } \\
\text { (EDPT } \\
831 \mathbf{\Delta})\end{array}$ & $\begin{array}{c}\text { tay- } \\
\text { 'sarmak, } \\
\text { sıkıca } \\
\text { bağlamak' } \\
\text { (EDPT 514) }\end{array}$ & $\begin{array}{c}\text { ban- } \\
\text { 'banmak, } \\
\text { daldırmak } \\
, \\
\text { (EDPT } \\
348 \boldsymbol{\nabla})\end{array}$ & $\begin{array}{c}\text { kañır-bk. } \\
\text { kađir- } \\
\text { 'kanırtmak' } \\
\text { (EDPT 604) }\end{array}$ \\
\hline
\end{tabular}




\begin{tabular}{|c|c|c|c|c|c|c|c|}
\hline & $\begin{array}{c}(\text { EDPT } \\
168 \boldsymbol{\nabla}) \\
\text { ey1 'en, } \\
\text { çok' } \\
(\text { EDPT } \\
166 \mathbf{\Lambda})\end{array}$ & $\begin{array}{c}\text { püskürt } \\
\text { mek' } \\
\text { (EDPT } \\
942 \mathbf{\Lambda}) \\
\\
\text { yanç- } \\
\text { 'ezmek, } \\
\text { çiğnem } \\
\text { ek; } \\
\text { buruştu } \\
\text { rmak' } \\
\text { (EDPT } \\
\text { 944 } \mathbf{\nabla}) \\
\text { yanu- } \\
\text { 'keskinl } \\
\text { eştirme } \\
\text { k, } \\
\text { bilemek } \\
\text { 'EDPT } \\
944 \mathbf{\Delta})\end{array}$ & & $\begin{array}{c}\text { sanç- } \\
\text { 'sançmak, } \\
\text { batırmak, } \\
\text { delmek, } \\
\text { deşmek' } \\
\text { (EDPT } \\
835 \text { V) } \\
\text { senir 'dağ } \\
\text { çıkıntısı' } \\
\text { EDPT } \\
840 \text { ム) }\end{array}$ & & & $\begin{array}{c}\text { kén 'geniş, } \\
\text { enli' } \\
\text { (EDPT } \\
724 \mathbf{\Lambda})\end{array}$ \\
\hline $\begin{array}{c}\text { in, } \\
\text { in } \\
n \sim y\end{array}$ & $\begin{array}{l}\text { in 'delik, } \\
\text { in' } \\
(\text { EDPT } \\
166 \mathbf{\nabla})\end{array}$ & 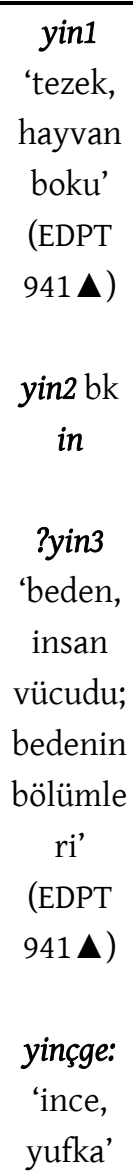 & $\begin{array}{c}\text { çı̀2 'tam, } \\
\text { bütün' } \\
\text { (EDPT } \\
424 \mathbf{\Delta} \text { ) } \\
\\
\text { ?çinke- } \\
\text { 'nakış } \\
\text { işlemek, } \\
\text { süsleme } \\
\text { yapmak; } \\
\text { düzlemek' } \\
\text { (EDPT } \\
416 \mathbf{\Delta} \text { ) }\end{array}$ & $\begin{array}{c}\text { sig- } \\
\text { 'sinmek, } \\
\text { dinmek' } \\
(\text { EDPT } \\
833 \mathbf{\nabla} \text { ) }\end{array}$ & * & $\begin{array}{c}\text { bin- } \\
\text { 'binmek' } \\
(\text { EDPT } \\
348 \mathbf{\Lambda})\end{array}$ & $\begin{array}{c}\text { kindik } \\
\text { 'göbek, } \\
\text { göbek } \\
\text { çukuru' bk. } \\
\text { kin (EDPT } \\
729 \mathbf{\Delta} \text { ) } \\
\\
\text { kinle- } \\
\text { 'klymak, } \\
\text { ezmek' bk. } \\
\text { *kin, simle- } \\
\text { (EDPT } \\
732 \mathbf{\nabla})\end{array}$ \\
\hline
\end{tabular}




\begin{tabular}{|c|c|c|c|c|c|c|c|}
\hline & & $\begin{array}{r}(\text { EDPT } \\
945 \mathbf{\Delta}) \\
\end{array}$ & & & & & \\
\hline $\begin{array}{l}u n, \\
u ̈ n \\
n \sim \eta\end{array}$ & $\begin{array}{c}\text { ün- } \\
\text { 'çıkmak, } \\
\text { doğmak, } \\
\text { yükselme } \\
\text { k' } \\
\text { (EDPT } \\
169 \text { \) } \\
\\
\text { üy- } \\
\text { 'oymak, } \\
\text { delmek' } \\
\text { (EDPT } \\
169 \mathbf{~ V ) ~}\end{array}$ & $\begin{array}{c}\text { yun1 } \\
\text { 'yün' } \\
\text { bk. yün, } \\
\text { tük } \\
\text { (EDPT } \\
941 \boldsymbol{\Delta})\end{array}$ & $*$ & $\begin{array}{c}\text { ?süy- } \\
\text { 'sünmek' } \\
\text { (EDPT } \\
834 \mathbf{\Lambda} \text { ) } \\
\text { sun- } \\
\text { 'sunmak, el } \\
\text { uzatmak; } \\
\text { dilek veya } \\
\text { armağan } \\
\text { sunmak' } \\
\text { (EDPT } \\
\text { 834 } \mathbf{\Lambda} \text { ) }\end{array}$ & $*$ & $\begin{array}{l}\text { bun ‘dip, } \\
\text { temel’ } \\
\text { (EDPT } \\
347 \mathbf{\nabla} \text { ) }\end{array}$ & $*$ \\
\hline $\begin{array}{l}\text { on, } \\
\text { ön } \\
n \sim \eta\end{array}$ & $\begin{array}{c}\text { ?on- } \\
\text { 'gelişmek } \\
; \\
\text { sağalmak } \\
\text {, } \\
(\text { EDPT } \\
168 \mathbf{\Lambda}) \\
\\
\text { op1- } \\
\text { 'solmak, } \\
\text { zayıflama } \\
\text { k, } \\
\text { sönmek' } \\
\text { (EDPT } \\
\text { 169 } \mathbf{\nabla})\end{array}$ & $\begin{array}{c}\text { yon- } \\
\text { 'yontma } \\
\text { k, } \\
\text { kesmek' } \\
\text { (EDPT } \\
942 \text { V) } \\
\\
\text { yöne- } \\
\text { bk. ün- }\end{array}$ & $\begin{array}{c}\text { çō } \\
\text { ‘büyük, } \\
\text { iri; } \\
\text { önemli’ } \\
\text { (EPTD } \\
424 \mathbf{\Lambda}) \\
\\
\text { çögek } \\
\text { ‘deriden } \\
\text { süt } \\
\text { kovası' } \\
\text { (EDPT } \\
426 \mathbf{\Delta})\end{array}$ & 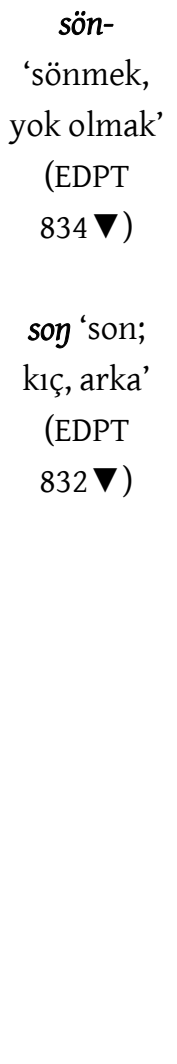 & $\begin{array}{l}\text { ton-'kapan } \\
\text { mak, } \\
\text { bağlanmak' } \\
\text { (EDPT } \\
514 \mathbf{\Lambda} \text { ) } \\
\text { ton- } \\
\text { 'donmak, } \\
\text { buz tutmak' } \\
\text { (EDPT } \\
515 \mathbf{\nabla} \text { ) } \\
\text { ton1 'tıkız, } \\
\text { yoğun, katı, } \\
\text { sert; çok } \\
\text { soğuk; buz, } \\
\text { don' (EDPT } \\
\text { 513 } \mathbf{\Delta} \text { ) }\end{array}$ & $\begin{array}{c}\text { bonçuk } \\
\text { 'boncuk' } \\
\text { (EDPT } \\
349 \text { ム) }\end{array}$ & 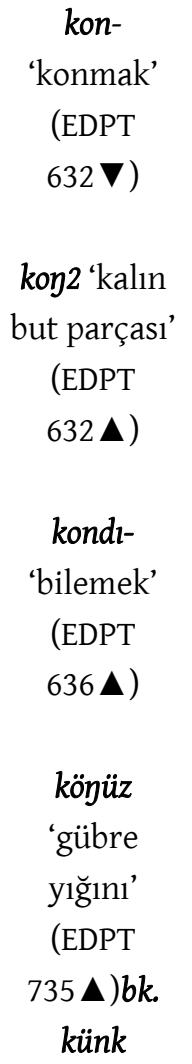 \\
\hline $\begin{array}{l}a r \\
e r\end{array}$ & $\begin{array}{c}\text { ar2 'arka' } \\
\text { (EDPT } \\
215 \mathbf{\Delta}) \\
\\
\text { ar1- } \\
\text { yorulma } \\
\text { k, }\end{array}$ & $\begin{array}{c}\text { yar- } \\
\text { 'yarmak } \\
\text {, } \\
\text { bölmek' } \\
\text { (EDPT } \\
954 \mathbf{\nabla})\end{array}$ & $\begin{array}{c}\text { çer1 } \\
\text { 'cüsse, } \\
\text { beden } \\
\text { büyüklüğg } \\
\text { ü' } \\
(\mathrm{EDPT} \\
427 \mathbf{\Delta})\end{array}$ & $\begin{array}{c}\text { sar- } \\
\text { ‘sarmak, } \\
\text { sarmalama } \\
\text { k' } \\
(\text { EDPT } \\
844 \mathbf{\Lambda})\end{array}$ & $\begin{array}{c}\text { tar-/ } \\
\text { tarıl-'saçma } \\
\text { k, } \\
\text { dağıtmak' } \\
\text { (EDPT } \\
529 \nabla)\end{array}$ & $\begin{array}{c}\text { bér- } \\
\text { 'vermek' } \\
(\text { EDPT } \\
354 \mathbf{\nabla})\end{array}$ & $\begin{array}{c}\text { kar2- } \\
\text { 'taşmak, } \\
\text { çıkmak, } \\
\text { yükselmek' } \\
\text { (EDPT } \\
643 \mathbf{\Delta})\end{array}$ \\
\hline
\end{tabular}




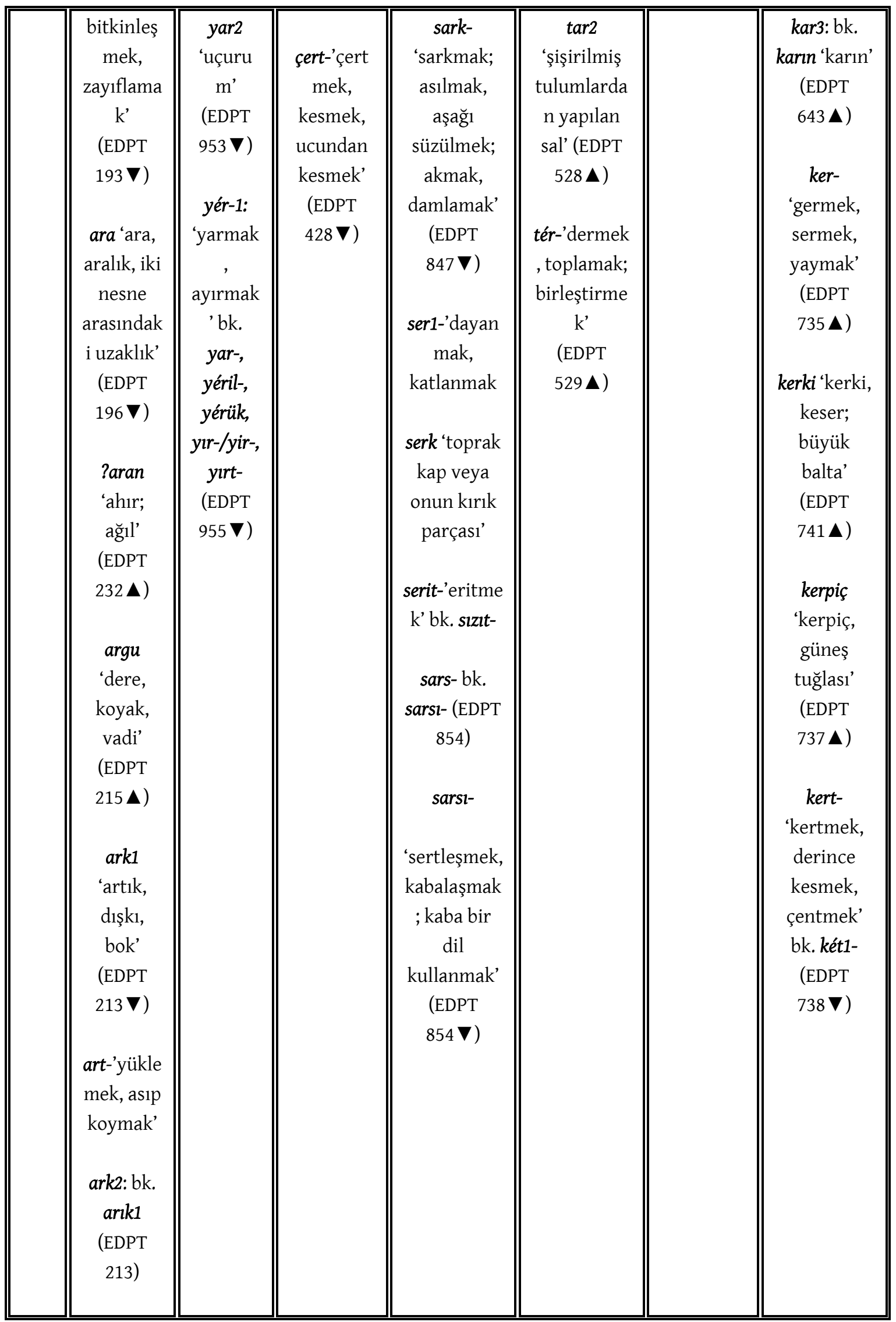




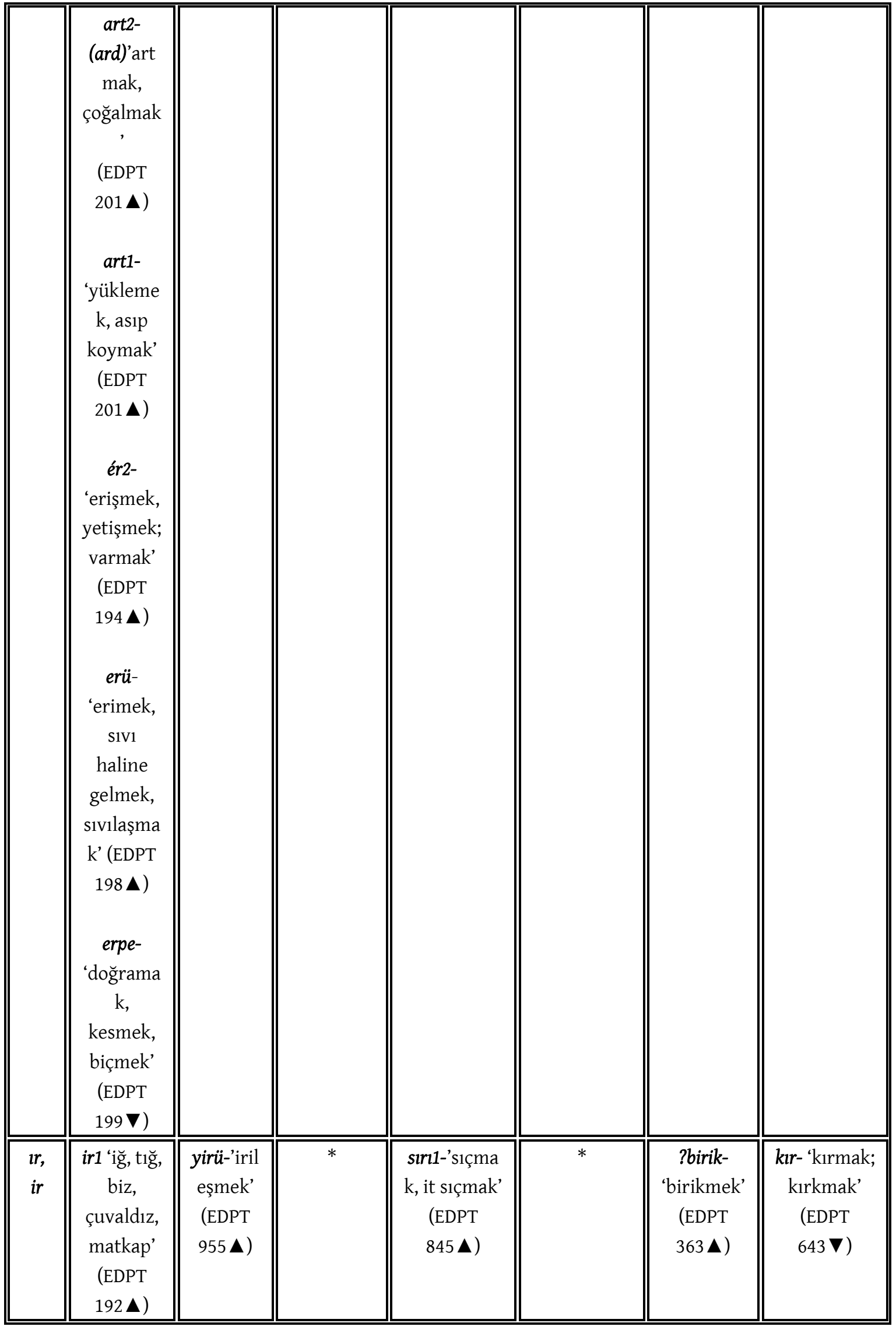


J(৫)

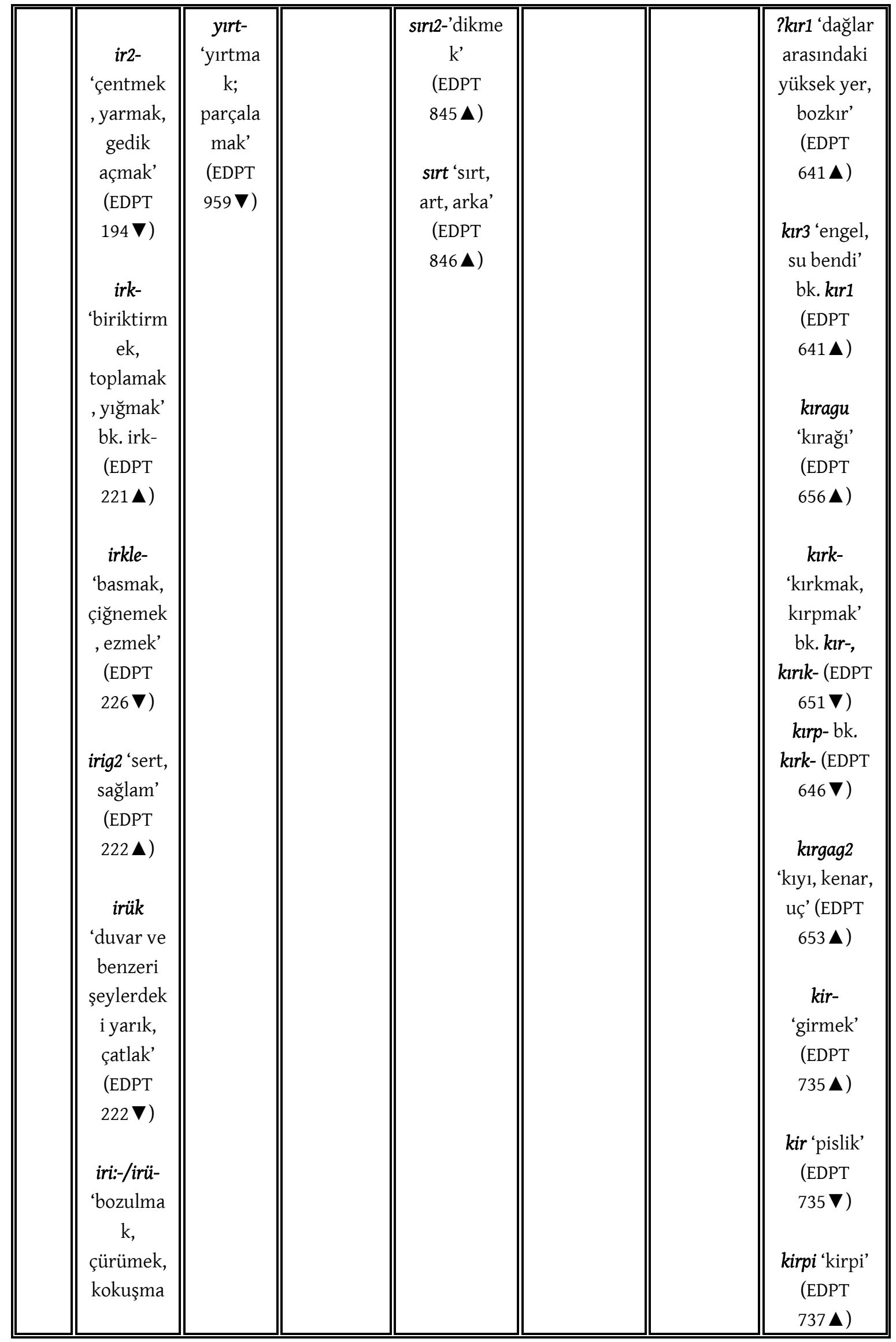




\begin{tabular}{|c|c|c|c|c|c|c|c|}
\hline & $\begin{array}{c}\text { k' (EDPT } \\
198 \boldsymbol{\nabla})\end{array}$ & & & & & & $\begin{array}{c}\text { kirpik } \\
\text { 'kirpik' bk. } \\
\text { kirpi (EDPT } \\
737 \mathbf{\Delta})\end{array}$ \\
\hline $\begin{array}{l}u r, \\
\text { ür }\end{array}$ & 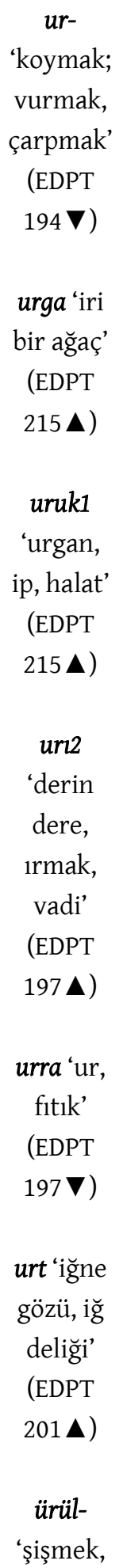 & $\begin{array}{c}\text { yurun } \\
\text { 'yama, } \\
\text { parça, } \\
\text { kırıntı' } \\
(\text { EDPT } \\
970 \Delta)\end{array}$ & $\begin{array}{c}\text { çurne 'toz' } \\
\text { (EDPT } \\
430 \boldsymbol{\Delta} \text { ) }\end{array}$ & $\begin{array}{c}\text { sür-/ sürt- } \\
\text { /sürç-'sürm } \\
\text { ek; } \\
\text { sürtmek' } \\
\text { (EDPT } \\
844 \text { М) }\end{array}$ & $\begin{array}{c}\text { tür- } \\
\text { ‘dürmek’ } \\
\text { (EDPT } \\
530 \mathbf{\Delta} \text { ) } \\
\text { türt- } \\
\text { ‘sürmek, } \\
\text { sürtmek, } \\
\text { ovmak; } \\
\text { dürtmek, } \\
\text { kışkırtmak’ } \\
\text { (EDPT } \\
535 \mathbf{\Lambda})\end{array}$ & $\begin{array}{c}\text { bür } \\
\text { 'tomur, } \\
\text { tomurcuk, } \\
\text { gonca' } \\
\text { (EDPT } \\
\text { 354 } \mathbf{\Lambda} \text { ) } \\
\text { bür- } \\
\text { 'bürmek, } \\
\text { büzmek, } \\
\text { bir araya } \\
\text { getirmek } \\
\text { (EDPT } \\
\text { 355 } \mathbf{\Lambda} \text { ) } \\
\text { ?bürge } \\
\text { 'pire' } \\
\text { (EDPT } \\
\text { 362 } \mathbf{\Lambda} \text { ) } \\
\text { bürt- } \\
\text { 'ellemek, } \\
\text { değmek, } \\
\text { dokunma } \\
\text { k' (EDPT } \\
\text { 358 } \mathbf{\Delta} \text { ) } \\
\text { büsinçek } \\
\text { 'üzüm } \\
\text { salkımı' } \\
\text { (EDPT } \\
\text { 383 } \mathbf{A} \text { ) }\end{array}$ & 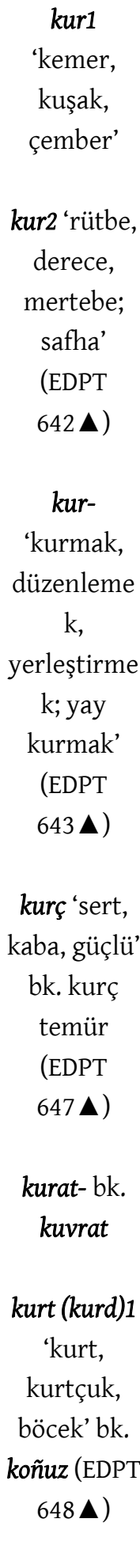 \\
\hline
\end{tabular}




\begin{tabular}{|c|c|c|c|c|c|c|c|}
\hline & $\begin{array}{c}\text { şişinmek, } \\
\text { üflenmek } \\
\text {, } \\
\text { (EDPT } \\
230 \mathbf{\Delta} \text { ) }\end{array}$ & & & & & & 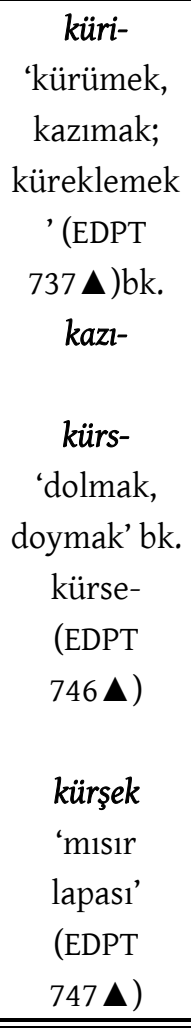 \\
\hline $\begin{array}{l}\text { or, } \\
\text { ör }\end{array}$ & 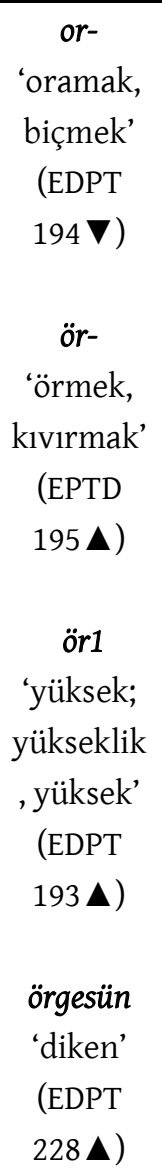 & $\begin{array}{c}\text { yör- } \\
\text { 'çözmek } \\
\text {, açmak' } \\
\text { (EDPT } \\
955 \mathbf{\Delta} \text { ) } \\
\text { yörge- } \\
\text { 'örtmek } \\
\text {, } \\
\text { sarmak, } \\
\text { sarıp } \\
\text { sarmala } \\
\text { mak; } \\
\text { beleme } \\
\text { k' bk. } \\
\text { çörge-, } \\
\text { (EDPT } \\
\text { 965 } \mathbf{\Delta} \text { ) }\end{array}$ & $\begin{array}{c}\text { çor1 } \\
\text { 'kagan ile } \\
\text { bey } \\
\text { arasında } \\
\text { yer alan } \\
\text { bir rütbe' } \\
\text { (EDPT } \\
427 \mathbf{\Lambda} \text { ) } \\
\text { çor2 'sık, } \\
\text { sıkı' } \\
\text { (EDPT } \\
428 \mathbf{\Delta} \text { ) } \\
\text { çörek } \\
\text { 'yuvarlak } \\
\text { ekmek } \\
\text { dilimi, } \\
\text { çörek' } \\
\text { (EDPT } \\
429 \mathbf{\Delta} \text { ) }\end{array}$ & $\begin{array}{c}\text { şor 'tuz; } \\
\text { tuzlu' } \\
\text { (EDPT } \\
868 \mathbf{\Lambda} \text { ) } \\
\text { sörple-'çek } \\
\text { mek, } \\
\text { sürüklemek } \\
\text { 'bk. sörile- } \\
\text { (EDPT } \\
845 \mathbf{\nabla} \text { ) }\end{array}$ & $\begin{array}{c}\text { tor 'tuzak, } \\
\text { balık veya } \\
\text { kuş kapan' } \\
\text { (EDPT } \\
528 \mathbf{\Delta}) \\
\\
\text { ?torum } \\
\text { 'deve } \\
\text { yavrusu, } \\
\text { dorum' } \\
\text { (EDPT } \\
549 \mathbf{\Delta}) \\
\text { tör 'yüksek } \\
\text { yer' } \\
\text { (EDPT } \\
528 \mathbf{\Delta}) \\
\text { törü- } \\
\text { 'türemek' } \\
\text { (EDPT } \\
533 \mathbf{\Delta})\end{array}$ & $\begin{array}{c}\text { borgu(y) } \\
\text { 'boru; } \\
\text { burgu' } \\
\text { (EDPT } \\
361 \mathbf{\Lambda}) \\
\text { börk 'börk, } \\
\text { başlik, } \\
\text { şapka' } \\
\text { (EDPT } \\
362 \mathbf{\Lambda})\end{array}$ & $\begin{array}{c}\text { kora- } \\
\text { 'azalmak, } \\
\text { kayba } \\
\text { uğramak' } \\
\text { (EDPT } \\
645 \mathbf{\nabla}) \\
\\
\text { korlan- } \\
\text { 'koyulaşma } \\
\text { k' bk. } \\
\text { kor2 } \\
\text { (EDPT } \\
659 \boldsymbol{\nabla})\end{array}$ \\
\hline
\end{tabular}




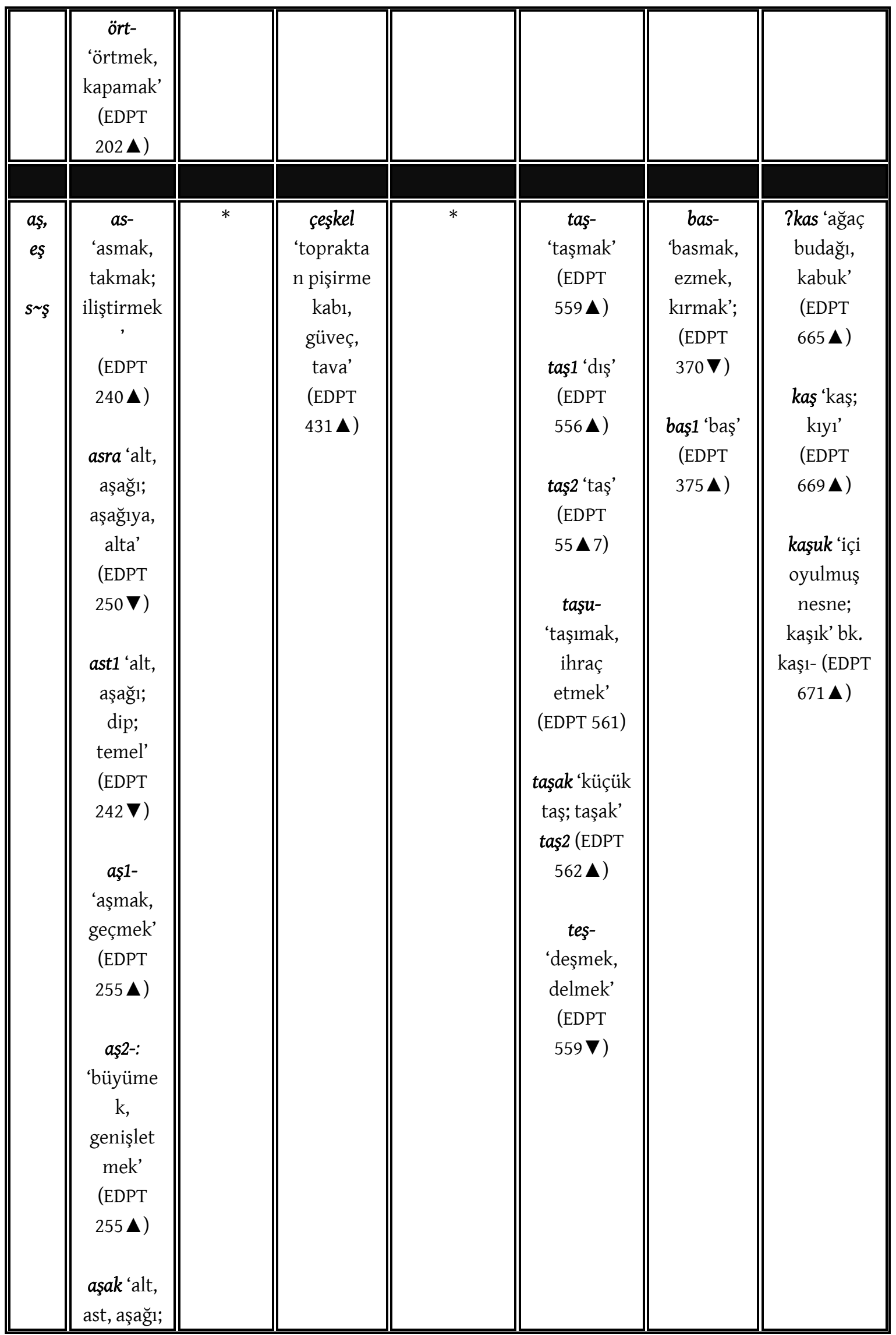




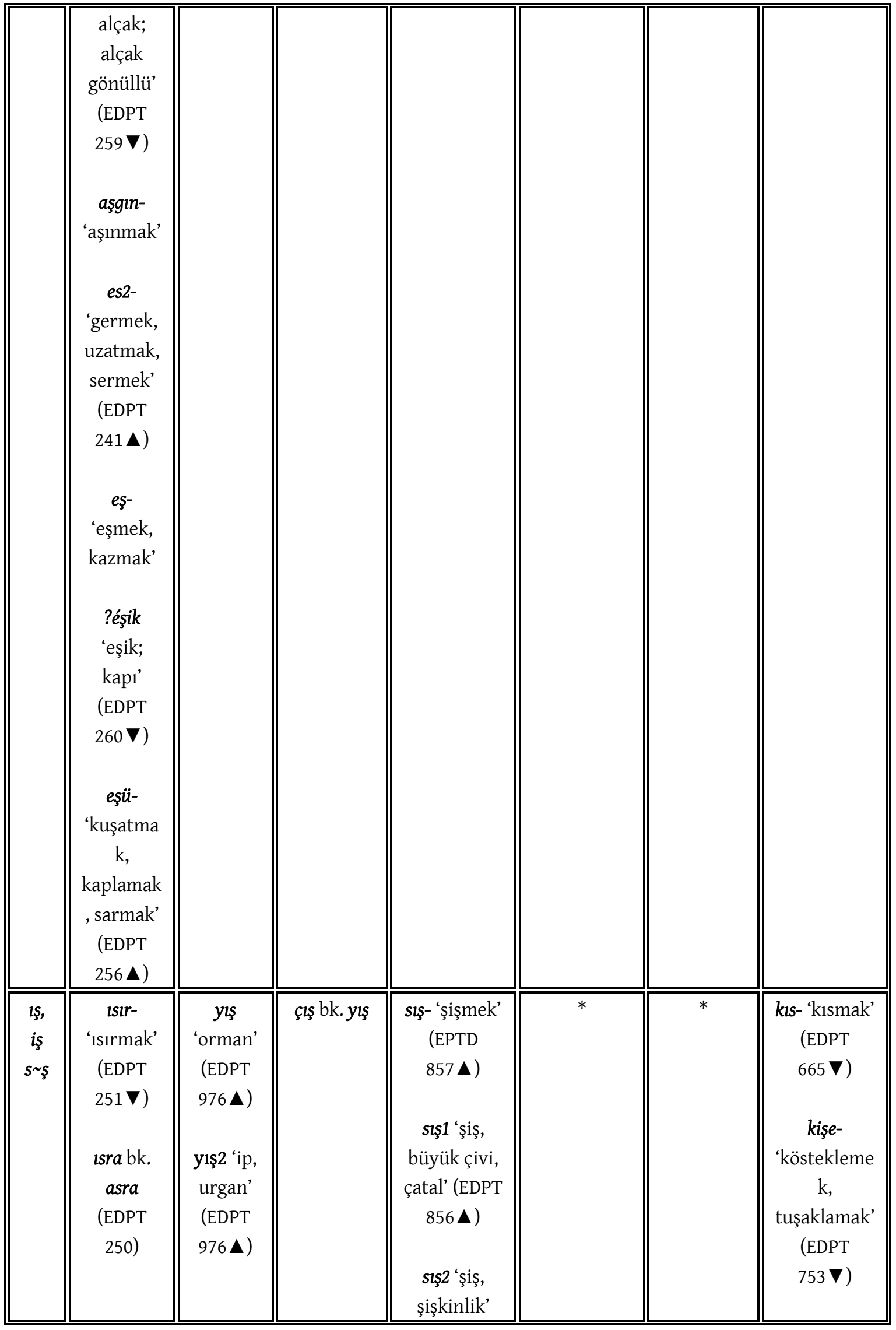


J(G)

\begin{tabular}{|c|c|c|c|c|c|c|c|}
\hline & & & & $\begin{array}{c}(\text { EDPT } \\
857 \mathbf{\Delta})\end{array}$ & & & \\
\hline $\begin{array}{l}\text { uş, } \\
\text { üs } \\
s \sim s\end{array}$ & $\begin{array}{c}\text { üş1- } \\
\text { 'üşmek, } \\
\text { üşusşmek, } \\
\text { toplanma } \\
\text { k, } \\
\text { yığılmak' } \\
\text { (EDPT } \\
256 \mathbf{\Delta} \text { ) } \\
\text { üss2-: } \\
\text { 'eşmek, } \\
\text { delmek, } \\
\text { deşmek' } \\
\text { (EDPT } \\
\text { 256 } \mathbf{\nabla} \text { ) } \\
\\
\text { ?üşi- } \\
\text { 'üşümek, } \\
\text { donmak' } \\
\text { (EDPT } \\
256 \mathbf{\nabla} \text { ) } \\
\text { üst } \\
\text { 'yukarı' } \\
\text { (EDPT } \\
242 \mathbf{\Delta} \text { ) }\end{array}$ & $*$ & $*$ & $\begin{array}{c}\text { susgak } \\
\text { 'kaşı veya } \\
\text { kepçe' bk. } \\
\text { (EDPT } \\
856 \mathbf{\Delta}) \\
\text { süs- } \\
\text { 'süsmek, } \\
\text { tosmak’ } \\
(\text { EDPT } \\
855 \mathbf{\nabla})\end{array}$ & $\begin{array}{l}\text { tuş2 'toka, } \\
\text { kopça' } \\
\text { (EDPT } \\
558 \mathbf{\Lambda}) \\
\text { tuş- } \\
\text { 'karşılaşma } \\
\text { k, denk } \\
\text { gelmek' } \\
\text { (EDPT } \\
560 \mathbf{\Lambda} \text { ) } \\
\text { tüş- 'inmek, } \\
\text { bir yere } \\
\text { yerleşmek' } \\
\text { (EDPT } \\
560 \mathbf{\nabla} \text { ) }\end{array}$ & $*$ & $\begin{array}{c}\text { kus- } \\
\text { 'kusmak' } \\
\text { (EDPT } \\
666 \mathbf{\nabla}) \\
\text { küskü ‘fare; } \\
\text { siçan' } \\
\text { (EDPT } \\
750 \mathbf{\Delta})\end{array}$ \\
\hline $\begin{array}{l}\text { oş, } \\
\text { öş } \\
\text { s ş }\end{array}$ & $\begin{array}{c}\text { ös- } \\
\text { büyümek } \\
, \\
\text { gelişmek' } \\
\text { (EDPT } \\
241 \mathbf{\Delta} \text { ) } \\
\\
\text { os- } \\
\text { 'slyırmak } \\
\text {, } \\
\text { kazımak, } \\
\text { koparma } \\
\text { k' } \\
\text { (EDPT } \\
241 \mathbf{\nabla})\end{array}$ & $*$ & $*$ & $*$ & $\begin{array}{c}\text { ?töşs 'göğüs, } \\
\text { göğsün üst } \\
\text { bölümü' } \\
(\text { EDPT } \\
558 \mathbf{\Lambda}) \\
\\
\text { töşe- } \\
\text { 'döşemek, } \\
\text { ser, } \\
\text { yazmak' } \\
\text { (EDPT } \\
561 \mathbf{\Delta} \text { ) bk. } \\
\text { tüşs }\end{array}$ & $\begin{array}{c}\text { boş 'boşta, } \\
\text { içi boş’ } \\
\text { (EDPT } \\
376 \mathbf{\nabla} \\
\text { bös-'sürü } \\
\text { mek, } \\
\text { sürüklem } \\
\text { ek; } \\
\text { dövmek } \\
\text { (EDPT } \\
\text { 371 } \mathbf{\nabla} \text { ) }\end{array}$ & $\begin{array}{c}\text { ?koş 'eş, } \\
\text { çiftlemek' } \\
\text { (EDPT } \\
670 \mathbf{\Delta}) \\
\text { koş- } \\
\text { 'eşlemek, } \\
\text { katmak; } \\
\text { bağlamak' } \\
\text { (EDPT } \\
670 \mathbf{\Lambda} \text { ) } \\
\\
\text { kösser- } \\
\text { 'dolmak, } \\
\text { dopdolu } \\
\text { olmak' }\end{array}$ \\
\hline
\end{tabular}




\begin{tabular}{|c|c|c|c|c|c|c|c|}
\hline & $\begin{array}{c}\text { osgun } \\
\text { 'soğan' } \\
\text { (EDPT } \\
245 \mathbf{\Lambda} \text { ) } \\
\\
\text { ?öşün } \\
\text { 'omuz; } \\
\text { boyun } \\
\text { kemiği' } \\
(\text { EDPT } \\
263 \mathbf{\Lambda})\end{array}$ & & & & & & $\begin{array}{c}\text { (EDPT } \\
754 \mathbf{\Lambda}) \\
\text { kösrük } \\
\text { 'köstek' } \\
(\text { EDPT } \\
751 \mathbf{\nabla})\end{array}$ \\
\hline $\begin{array}{l}a t, \\
e t ; \\
a d, \\
e d \\
d \sim y\end{array}$ & $*$ & $\begin{array}{c}\text { yét1- } \\
\text { 'yedekle } \\
\text { mek' } \\
\text { (EDPT } \\
884 \mathbf{\Delta})\end{array}$ & $\begin{array}{c}\text { çat- } \\
\text { 'çatmak, } \\
\text { birleştirm } \\
\text { ek, } \\
\text { bağlamak) } \\
\text {, } \\
\text { (EDPT } \\
402 \mathbf{\Lambda}) \\
\text { çat2 'kuyu' } \\
\text { (EDPT } \\
401 \mathbf{\nabla}) \\
\\
\\
\text { çetken } \\
\text { 'yular, } \\
\text { dizgin; } \\
\text { bağlama } \\
\text { işi' } \\
\text { (EDPT } \\
402 \mathbf{\Lambda})\end{array}$ & $\begin{array}{l}\text { seđre- 'geniş } \\
\text { aralıklarla } \\
\text { dikilmek; } \\
\text { ayrilmak, } \\
\text { çözülmek, } \\
\text { seyrekleşm } \\
\text { ek; } \\
\text { gevşemek' } \\
\text { (EDPT } \\
802 \text { V) }\end{array}$ & $\begin{array}{c}\text { ?tadu } \\
\text { 'tabiat, } \\
\text { doğa; } \\
\text { doğadaki } \\
\text { element; } \\
\text { bedenin } \\
\text { temel } \\
\text { unsuru' } \\
\text { (EDPT } \\
451 \mathbf{\Lambda})\end{array}$ & $\begin{array}{c}\text { bat1 } \\
\text { 'bütün, } \\
\text { hep, } \\
\text { tamamen' } \\
\text { (EDPT } \\
296 \mathbf{\Lambda} \text { ) } \\
\text { bat- } \\
\text { 'batmak' } \\
\text { (EDPT } \\
298 \mathbf{\nabla} \text { ) } \\
\text { baynak } \\
\text { 'gübre, } \\
\text { bok' } \\
\text { (EPTD } \\
350 \mathbf{\Lambda} \text { ) }\end{array}$ & $\begin{array}{c}\text { kat- } \\
\text { 'eklemek, } \\
\text { ilave } \\
\text { etmek' } \\
\text { (EDPT } \\
594 \mathbf{\Delta}) \\
\text { kađır 'kaba, } \\
\text { sert' } \\
\text { (EPTD } \\
603 \mathbf{\nabla}) \\
\\
\text { kađir- } \\
\text { 'kanırmak, } \\
\text { çevirmek, } \\
\text { geriye } \\
\text { bükmek' } \\
\text { (EDPT } \\
\text { 604 } \mathbf{\nabla}) \\
\text { ked 'çok, } \\
\text { artık, fazla' } \\
\text { (EDPT } \\
700 \mathbf{\Lambda}) \\
\text { kay- } \\
\text { (*kađ2-): } \\
\text { 'kıvrılmak, } \\
\text { eğrilmek, } \\
\text { bükülmek' } \\
\text { (EDPT } \\
674 \mathbf{\nabla})\end{array}$ \\
\hline
\end{tabular}




\begin{tabular}{|c|c|c|c|c|c|c|c|}
\hline & & & & & & & $\begin{array}{c}\text { kaya1 'kaya; } \\
\text { yar, } \\
\text { uçurum' } \\
\text { (EDPT } \\
674 \mathbf{\Delta} \text { ) }\end{array}$ \\
\hline $\begin{array}{c}\text { it, } \\
i t ; \\
\imath d, \\
i d \\
d \sim y\end{array}$ & $*$ & * & $\begin{array}{c}\text { çıt } \\
\text { 'parmaklı } \\
\text { k' } \\
(\text { EDPT } \\
401 \mathbf{\Delta})\end{array}$ & $\begin{array}{l}\text { sidır- > slyır- } \\
\text { 'ayırmak, } \\
\text { bölmek' } \\
\text { (EDPT } \\
799 \mathbf{\nabla}) \\
\\
\text { sitga- } \\
\text { 'dürmek, } \\
\text { katlamak, } \\
\text { sarmak' bk. } \\
\text { sıga- (EDPT } \\
800 \mathbf{\Delta} \text { ) }\end{array}$ & $\begin{array}{c}\text { ?ttt- } \\
\text { 'ditmek, } \\
\text { koparmak' } \\
(\text { EDPT } \\
450 \nabla) \\
\text { titig2 } \\
\text { 'çamur, } \\
\text { balçık' } \\
(\text { EDPT } \\
455 \mathbf{\Delta}) \\
\text { tıđ- } \\
\text { 'tıkamak, } \\
\text { kapamak' } \\
\text { (EDPT } \\
450 \mathbf{\nabla})\end{array}$ & bk. büt- & $\begin{array}{c}\text { kıd- } \\
\text { 'klymak, } \\
\text { kesmek' } \\
\text { (EDPT } \\
595 \mathbf{\nabla} \text { ) }\end{array}$ \\
\hline $\begin{array}{l}\text { ut, } \\
\text { üt; } \\
\text { ud, } \\
\text { üd }\end{array}$ & $\begin{array}{c}\text { uđuu1 } \\
\text { 'yığın, } \\
\text { küme, } \\
\text { öbek, } \\
\text { tepecik' } \\
\text { (EDPT } \\
42 \mathbf{\Delta}) \\
\\
\text { ?uđt- } \\
\text { 'uyumak; } \\
\text { kesilmek, } \\
\text { pıhtılaşm } \\
\text { ak; } \\
\text { uyuşmak' } \\
\text { (EDPT } \\
\text { 42 } \mathbf{\nabla} \text { ) } \\
\text { uđluk } \\
\text { 'uyluk } \\
\text { kemiği, } \\
\text { kalça, }\end{array}$ & $\begin{array}{c}\text { yut- } \\
\text { 'yutmak } \\
\text { '(EDPT } \\
885 \text { V) } \\
\\
\text { yüđ-'yü } \\
\text { klenme } \\
\text { k, } \\
\text { taşımak' } \\
\text { (EDPT } \\
910 \mathbf{A} \text { ) } \\
\\
\text { yudrukla } \\
n- \\
\text { 'yumruk } \\
\text { lanmak, } \\
\text { yumruk } \\
\text { larını } \\
\text { sikmak' } \\
\text { bk. } \\
\text { yudruk, }\end{array}$ & * & $\begin{array}{c}\text { şut 'kök, } \\
\text { dip; kaynak' } \\
\text { (EDPT } \\
867 \text { V) }\end{array}$ & $\begin{array}{c}\text { tut- } \\
\text { 'tutmak, } \\
\text { yakalamak, } \\
\text { kavramak' } \\
\text { (EDPT } \\
451 \mathbf{\Delta})\end{array}$ & 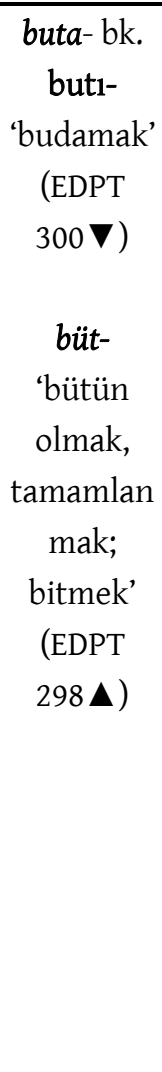 & $\begin{array}{c}\text { kutu 'kutu' } \\
\text { (EDPT } \\
596 \mathbf{\Delta}) \\
\text { kuđz-'koyma } \\
\text { k, dökmek } \\
\text { (EDPT } \\
596 \mathbf{\nabla}) \\
\text { kutur1- } \\
\text { 'dökmek, } \\
\text { boşaltmak' } \\
\text { (EDPT } \\
605 \mathbf{\nabla})\end{array}$ \\
\hline
\end{tabular}




\begin{tabular}{|c|c|c|c|c|c|c|c|}
\hline & $\begin{array}{c}\text { but' bk. } \\
\text { ud (EDPT } \\
55 \mathbf{\Delta} \text { ) } \\
\text { üt (üd) } \\
\text { 'delik, } \\
\text { açıklık' } \\
\text { (EDPT } \\
36 \mathbf{\nabla})\end{array}$ & $\begin{array}{c}\text { yldruk } \\
\text { 'yumru } \\
\text { k' } \\
(\text { EDPT } \\
893 \mathbf{\Lambda})\end{array}$ & & & & & \\
\hline $\begin{array}{l}\text { ot, } \\
\text { öt; } \\
\text { od, } \\
\text { öd } \\
d \sim y\end{array}$ & $*$ & $\begin{array}{c}\text { yota } \\
\text { 'uyluk, } \\
\text { but, } \\
\text { apış; } \\
\text { dağ } \\
\text { tepesi, } \\
\text { doruk, } \\
\text { zirve' } \\
\text { (EDPT } \\
886 \mathbf{\Delta} \text { ) } \\
\text { yod bk. } \\
\text { yok } \\
\text { yot- } \\
\text { 'y1kmak } \\
\text {, } \\
\text { bozmak; } \\
\text { silmek' } \\
\text { (EDPT } \\
885 \mathbf{\nabla} \text { ) }\end{array}$ & $*$ & $*$ & $\begin{array}{c}\text { tođ- } \\
\text { 'doymak, } \\
\text { dolmak' } \\
\text { (EDPT } \\
451 \mathbf{\Lambda}) \\
\\
\text { tođun 'köy } \\
\text { başkanı, } \\
\text { tudun' } \\
\text { (EDPT } \\
457 \mathbf{\Lambda})\end{array}$ & $\begin{array}{c}\text { bođu2- } \\
\text { 'bağlamak } \\
\text {, } \\
\text { çivilemek' } \\
\text { bk. bodul- } \\
\text { (EDPT } \\
300 \text { A) }\end{array}$ & $\begin{array}{c}\text { kođ-'koyma } \\
\text { k' } \\
\text { (EDPT } \\
595 \mathbf{\Delta}) \\
\text { kođı 'aşağı, } \\
\text { aşağıya, } \\
\text { aşağıya } \\
\text { doğru' } \\
\text { (EDPT } \\
596 \mathbf{\nabla} \text { ) } \\
\text { kötï 'evin } \\
\text { tavanı, çatı' } \\
\text { (EDPT } \\
\text { 701 } \mathbf{\Delta} \text { ) } \\
\text { kötki 'tepe, } \\
\text { tümsek; } \\
\text { yüksek yer' } \\
\text { (EDPT } \\
\text { 702 } \mathbf{\Delta} \text { ) }\end{array}$ \\
\hline $\begin{array}{l}a v \\
e v\end{array}$ & $\begin{array}{c}a v- \\
\text { 'toplama } \\
\text { k, } \\
\text { yığmak' } \\
\text { (EDPT } \\
4 \mathbf{\Lambda} \text { ) } \\
\\
\text { evdi- } \\
\text { 'yığmak, } \\
\text { devşirme } \\
\text { k, } \\
\text { toplamak }\end{array}$ & $\begin{array}{l}\text { yava1? } \\
\text { 'yabani } \\
\text { soğan' } \\
\text { (EDPT } \\
871 \mathbf{\Lambda} \text { ) }\end{array}$ & * & F* & $\begin{array}{c}\text { tev- } \\
\text { 'delmek, } \\
\text { şişlemek; } \\
\text { çizmek, } \\
\text { kazımak, } \\
\text { tımalamak' } \\
\text { (EDPT } \\
435 \mathbf{\nabla})\end{array}$ & * & $\begin{array}{c}\text { kav-* bk. } \\
\text { kavir-, kavıs- } \\
\text { (EDPT 580) } \\
\text { kavir- } \\
\text { 'toplamak, } \\
\text { ylğmak, bir } \\
\text { araya } \\
\text { getirmek' } \\
\text { (EPTD } \\
585 \mathbf{\Delta} \text { ) }\end{array}$ \\
\hline
\end{tabular}




\begin{tabular}{|c|c|c|c|c|c|c|c|}
\hline & $\begin{array}{l}\text { '(EDPT } \\
7 \mathbf{\Lambda}) \\
\text { ?evin } \\
\text { 'çekirdek, } \\
\text { tohum' } \\
(\text { EDPT } \\
12 \mathbf{\Delta})\end{array}$ & & & & & & $\begin{array}{c}\text { kavuk kese, } \\
\text { sidik } \\
\text { torbas1, } \\
\text { mesane' } \\
(\text { EDPT } \\
583 \mathbf{\Delta}) \\
\\
\text { kev- } \\
\text { 'gevmek, } \\
\text { çiğnemek; } \\
\text { gevelemek' } \\
\text { (EDPT } \\
687 \mathbf{\Delta}) \\
\end{array}$ \\
\hline $\begin{array}{l}i v, \\
i v\end{array}$ & * & $\begin{array}{c}y \imath<y i g i \\
\text { 'dar, } \\
\text { yoğun' } \\
(\text { EDPT } \\
911 \mathbf{\Delta})\end{array}$ & $\begin{array}{c}\text { çıw (?çı): } \\
\text { 'uç, köşe' } \\
\text { (EDPT } \\
393 \mathbf{\Lambda}) \\
\text { çiv-* bk. } \\
\text { çivgin } \\
\text { (EDPT } \\
\text { 394) } \\
\text { çivgin } \\
\text { 'şişmanlat } \\
\text { 1C1, } \\
\text { besleyici' } \\
\text { bk. kevgin } \\
\text { (EDPT } \\
\text { 396 \) }\end{array}$ & * & * & $*$ & $\begin{array}{c}\text { ?klvir- } \\
\text { 'kıvirmak' }\end{array}$ \\
\hline $\begin{array}{l}u v, \\
\ddot{u} v\end{array}$ & $\bar{~}$ & $\bar{~}$ & $\bar{~}$ & $\begin{array}{c}\text { suva-bk. } \\
\text { siba-, suba-, } \\
\text { stva-, suval-, } \\
\text { suvas- } \\
\text { 'sivamak' } \\
\text { (EDPT } \\
785 \text { ム) } \\
\text { süvri 'sivri' } \\
\text { (EDPT } \\
791 \text { ム) }\end{array}$ & $\begin{array}{l}\text { bk. tüg- } \\
\text { tuvir- } \\
\text { 'dikmek, } \\
\text { batırmak' } \\
\text { (EDPT } \\
443 \mathbf{\nabla})\end{array}$ & $*$ & $\begin{array}{c}\text { küve- } \\
\text { ‘şişinmek' } \\
\text { (EDPT } \\
690 \mathbf{\nabla}) \\
\text { küvlük } \\
\text { 'misket ve } \\
\text { mermi } \\
\text { olarak } \\
\text { kullanılan } \\
\text { çamur } \\
\text { topak’ } \\
\text { (EDPT } \\
689 \mathbf{\Delta} \text { ) }\end{array}$ \\
\hline
\end{tabular}




\begin{tabular}{|c|c|c|c|c|c|c|c|}
\hline & & & & & & & $\begin{array}{c}\text { kuvra-'topla } \\
\text { nmak, bir } \\
\text { araya } \\
\text { gelmek' } \\
\text { (EDPT } \\
586 \mathbf{\Delta}) \\
\\
\text { küveç } \\
\text { 'göveç, iri } \\
\text { toprak kap' } \\
\text { bk. kuzeç } \\
\text { (EDPT } \\
687 \mathbf{\Delta}) \\
\end{array}$ \\
\hline $\begin{array}{l}o v, \\
o ̈ v\end{array}$ & $\begin{array}{l}\text { bk. og- } \\
\text { bk. ög- }\end{array}$ & $\begin{array}{c}\text { ?yovuş3- } \\
\text { 'bölüşm } \\
\text { ek' } \\
\text { (EDPT } \\
881 \mathbf{\Delta} \text { ) } \\
\text { yövtür- } \\
\text { 'toplat } \\
\text { mak, } \\
\text { yığdırm } \\
\text { ak' } \\
\text { (EDPT } \\
873 \mathbf{\Delta} \text { ) }\end{array}$ & $*$ & $*$ & $\begin{array}{c}\text { tovra- } \\
\text { 'irileşmek' } \\
(\text { EDPT } \\
444 \mathbf{\Lambda})\end{array}$ & $*$ & $\begin{array}{c}\text { kövre } \\
\text { 'gövde, } \\
\text { beden' } \\
\text { (EDPT } \\
690 \mathbf{\Delta} \text { ) } \\
\text { ?kövürgen } \\
\text { 'yaban } \\
\text { soğan' } \\
\text { (EPTD } \\
691 \mathbf{\Lambda}) \\
\text { kovuk } \\
\text { 'kovuk, } \\
\text { oluk, oyuk' } \\
\text { (EDPT } \\
583 \mathbf{\nabla} \text { ) } \\
\end{array}$ \\
\hline $\begin{array}{l}a z, \\
e z\end{array}$ & $\begin{array}{c}\text { az- } \\
\text { 'azmak, } \\
\text { şaşmak; } \\
\text { yoldan' } \\
\text { (EDPT } \\
279 \text { V) } \\
\\
\text { az1 'az; } \\
\text { birkaç; } \\
\text { küçük, } \\
\text { ufak' } \\
\text { (EDPT } \\
277 \mathbf{\nabla}) \\
\end{array}$ & * & F* & F* & $\begin{array}{c}\text { tezek 'tezek, } \\
\text { hayvan } \\
\text { boku' } \\
(\text { EDPT } \\
574 \mathbf{\Lambda})\end{array}$ & $\begin{array}{c}\text { bazgan } \\
\text { 'demirci } \\
\text { çekici' bk. } \\
\text { bas-, } \\
\text { basğan, } \\
\text { baltaçuk, } \\
\text { yaltçuk } \\
\text { (EDPT } \\
390 \text { ム) } \\
\text { *bez- } \\
\text { 'bezmek' }\end{array}$ & $\begin{array}{c}\text { kaz- } \\
\text { 'kazmak, } \\
\text { kazımak, } \\
\text { eşmek' } \\
\text { (EDPT } \\
680 \mathbf{V}) \\
\\
\text { kazı- } \\
\text { 'kazımak, } \\
\text { sıyırmak, } \\
\text { oymak, } \\
\text { kaşımak; } \\
\text { sürtmek, }\end{array}$ \\
\hline
\end{tabular}




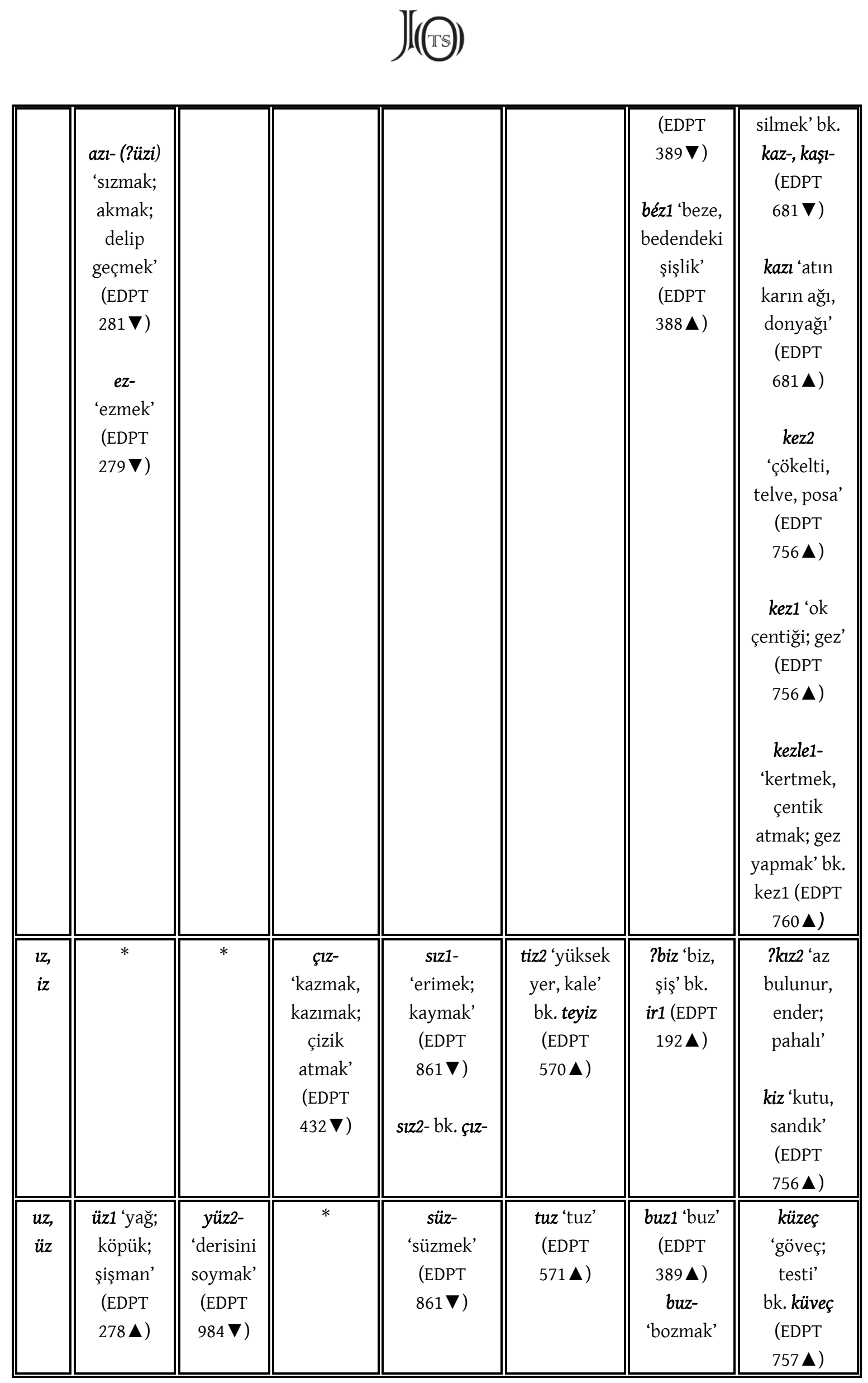




\section{Ј((马)}

\begin{tabular}{|c|c|c|c|c|c|c|c|}
\hline & $\begin{array}{c}\text { bk. üs, } \\
\text { üz-, yüz } \\
\text { üz- } \\
\text { 'yırtmak, } \\
\text { koparma } \\
\text { k' } \\
\text { (EDPT } \\
279 \text { V) } \\
\text { üze 'üst, } \\
\text { yukarı' } \\
\text { (EDPT } \\
280 \text { \) }\end{array}$ & & & & & $\begin{array}{c}\text { (EDPT } \\
390 \boldsymbol{\nabla}) \\
\text { ?büz- bk. } \\
\text { bür- } \\
\text { (EDPT } \\
\text { 355) }\end{array}$ & \\
\hline $\begin{array}{l}o z, \\
o z z\end{array}$ & $\begin{array}{c}\text { oz- } \\
\text { ‘aşmak, } \\
\text { üstesinde } \\
\text { n gelmek } \\
\text { (EDPT } \\
279 \mathbf{\Delta})\end{array}$ & $*$ & $\begin{array}{c}\text { çöz- çöj- } \\
\text { 'çözmek' } \\
(\text { EDPT } \\
400 \boldsymbol{\nabla})\end{array}$ & $*$ & $\begin{array}{c}\text { toz1 'toz' } \\
\text { (EDPT } \\
570 \mathbf{\Lambda}) \\
\text { toz- } \\
\text { 'tozmak' } \\
\text { (EDPT } \\
572 \mathbf{\Lambda} \text { ) } \\
\text { töz 'kök, } \\
\text { temel, } \\
\text { kaynak' } \\
\text { (EDPT } \\
571 \mathbf{\Lambda})\end{array}$ & $\begin{array}{c}\text { ?boz 'boz' } \\
\text { (EDPT } \\
388 \boldsymbol{\Delta} \text { ) }\end{array}$ & $\begin{array}{c}\text { köz2 ‘köz, } \\
\text { kor’ } \\
\text { (EDPT } \\
756 \text { ム) }\end{array}$ \\
\hline
\end{tabular}

Tablo 4 Seçili Anlam Alanının Kök Dal Biçimleri

3. Sonuç Yerine: Kök Dal Biçimlere Ulaşmada Hece Yönteminin İşlevselliğinin Sorgulanması

Sadece biçimsel yapı üzerinden sözcük kök ve gövdesine yaklaşıldığında anlamın geniş ve karmaşık alanı genellikle göz ardı edildiğinden elde edilecek kök dal biçimler de kısıtlı sayıda olacaktır. Bu durum şekil 1' de örneklendirilmiştir: 


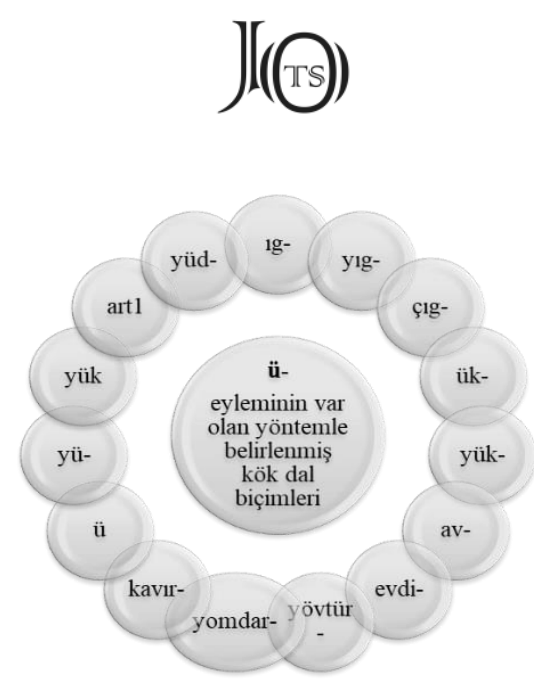

Şekil 1

Şekil 1'in üye sayısıyla Tablo 5'teki üye sayısı arasında çok büyük bir fark olduğu görülmektedir. Yine benzer bir biçimde kök dal biçimlere ulaşmada var olan yaklaşım kullanılarak ilgili sözlükte tarama yapıldığında $ı, y l$ - ve yış 'orman' sözcüklerinin her birine biraz daha detaylı bir tutumla ulaşmak bir derece mümkündür. Ancak bük1 'çalılık, fundalık; orman' sözcüğüne ulaşılmak isteniyorsa çalışma boyunca anlattığımız yöntemin kullanılması gerekecektir. Aynı şekilde todun 'köy başkanı' ve çupan 'köy başkanı” arasında ilişki yukarıda değinilen durumu desteklemektedir. Ayrıca, sözcük kök ve gövdelerinin olumsuz uçları ise yukarıdaki şekilde yer al(a)mamıştır. Oysa, dilin diyalektik yapısı gereği 'iki uçlu' yapıların kök dal biçim taramasında elde edilmesi beklendik bir durum olmaliyd.

Daha önce de dile getirildiği üzere 654 kök dal biçimin tek tek incelenmesi makale olarak yayımlanacak bu çalışma için oldukça fazla olacağından bundan sonra paylaşacağımız anlam alanı odaklı Şekil 2-9, çalışmanın sayıltısıyla ilgili bir fikir verebilecektir:

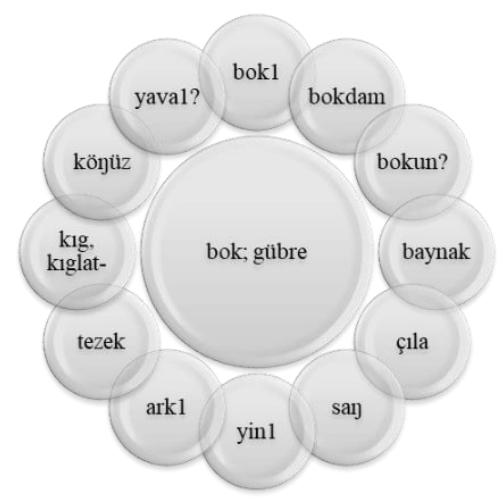

Şekil 2 
Şekil 3’te görüldüğü üzere bok, gübre sözcükleri farklı hece tabanları ve önses girişlerinde, aynı anlam alanıyla 12 adet kök dal biçimle temsil edilmektedir. Ayrı bir anlam odaklı şekil üzerinde bu dal kök biçimleri vermek onların farklı kök dal biçimlerden oluştuğu anlamına gelmemelidir. Çalışmanın en başında sınırları çizilen anlam alanına bakıldığında yukarıdaki sözcük kök ve gövdelerinin tamamının birikme, yığılma, katılaşma vb. süreçler sonrasında oluşan varlıklar olduğu açıktır. Bilgilere ad olan sözcükler de sıradüzensel bir gelişme düzeneğine tabiidir. Nasıl ki göz sözcüğü olmadan gözcü sözcüğü olamayacaksa buradaki kök dal biçimler de kendi 'göz'elerine bağlıdır, bağımlıdır.

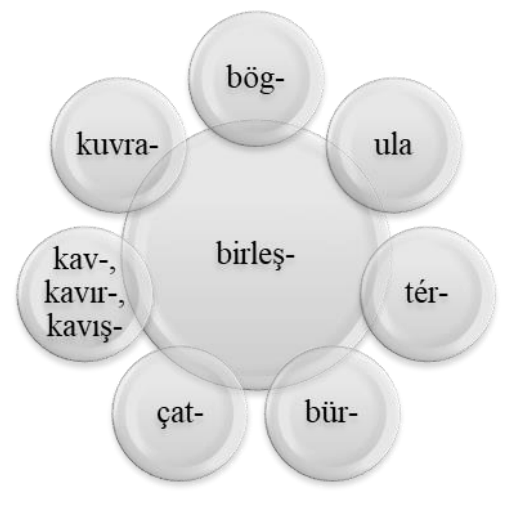

Şekil 3

Burada ise birleş- eyleminin 7 farklı kök dal biçimle temsil edildiği görülmektedir. Dikkat çeken nokta ise anlamın Türkçe gibi sondan eklemi bir dilde ön hecelerde değil, son hecelerde korunmasıdır. Çalışmanın başından beri dile getirdiğimiz önses girişleri sözcük kök ve gövdelerine bir anlam kazandırmaktan öte yalnızca biçimce bir değişiklik yapmaktadır. Genel bir yaklaşımla bu anlam odağındaki kök dal biçimlere bakılsa çat-, bür-, tér- ve hatta bög- eylemleri muhtemelen görmezden gelinecekti. Oysa birleş- eyleminin anlamına bakıldığında dikkat çeken ilk şeyin birden fazla varlığın bir araya gelmesiyle oluşan bütünlük olduğu gözden kaçırılmamalıdır. $\mathrm{Bu}$ açıdan yaklaşıldığında çat-, bür-, tér- ve hatta bög- gibi eylemlerin burada olmaması için hiçbir neden yoktur. 


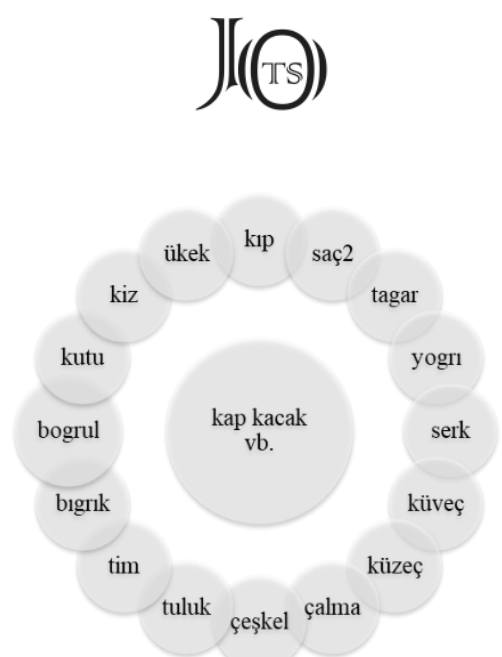

Şekil 4

Çalışmanın yöntem başlı̆̆ı altında dile getirilen koşullar çerçevesinde yapılan sözlük taramasında elde edilen kök dal biçimler şekil 4’te verilmiştir. Yine, diğerlerinde olduğu gibi, aynı anlam alanı içerisinde ve günlük kullanım amacı açısından aynı konumda 16 sözcük biçimce başka yapılarda olmasına rağmen bu çalışmada bahsedilen yöntemle tespit edilebilmiştir. Aşağıda anlam odaklı hazırlanan diğer kök dal biçimlerde de bu durumu gözlemlemek mümkündür.

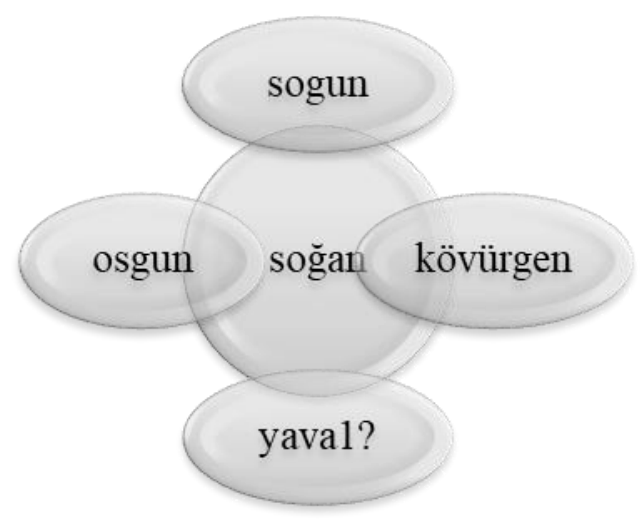

Şekil 5

Soğan sözcüğünün kök dal biçimleri ise şu sözcüklerden oluşmaktadır. Tekrara düşmeden bu kök dal biçimlerle ilgili birkaç şey dile getirilmelidir: sogun, osgun, kövürgen ve yaval? sözcüklerinde koyu olarak vurguladığımı bölümlerin aynı kökten dallandığı görülebilmektedir. Devamındaki ek veya ekler ise, temelde, sözcüğe yeni bir biçim kazandırmanın ötesinde farklı bir işlev taşımamaktadır. 


\section{J(O)}

Belirli ses denklikleriyle saptanamayacak kadar karmaşı olan tepe, zirve vb. anlam alanı bağlamında ulaştığımız kök dal biçimler ise şekil 6'da gösterilmektedir:

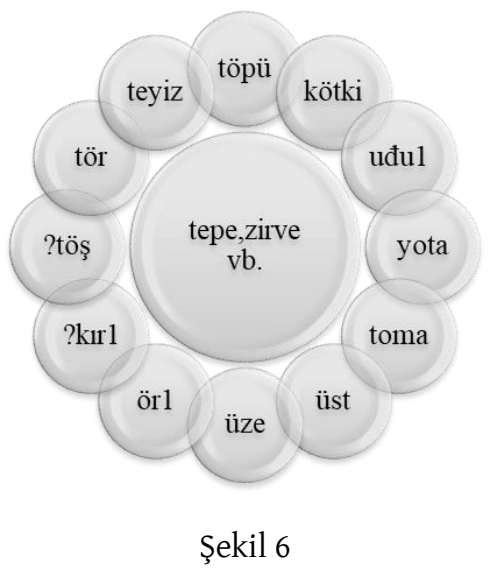

Şekil 7'de aynı anlam alanının süreç içindeki değişikliklerle oluşan ayrık bir anlamsal bağlamın kök dal biçimleri örneklendirilmektedir:

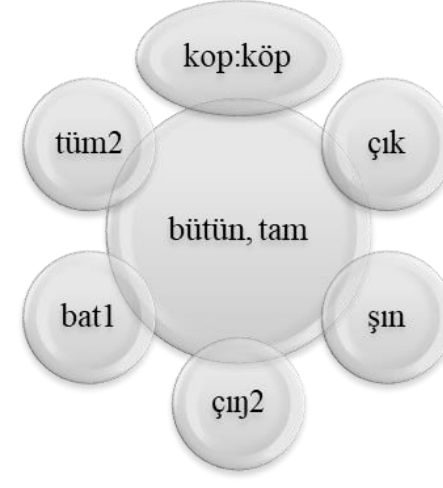

Şekil 7

Şekil 8 ve 9'da hece tabanları ve önses kesişimi sonrasında elde edilen kök dal biçimler ise şunlardır:

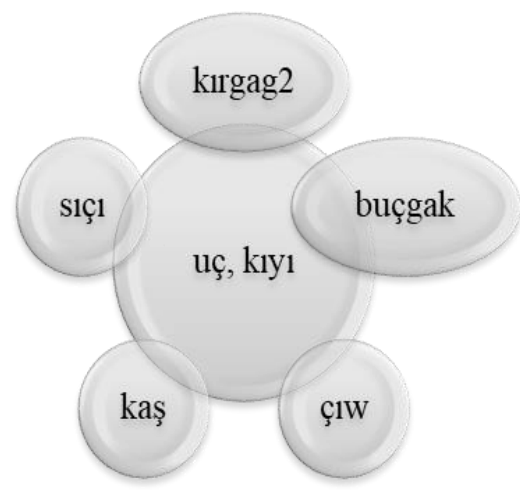

Şekil 8 


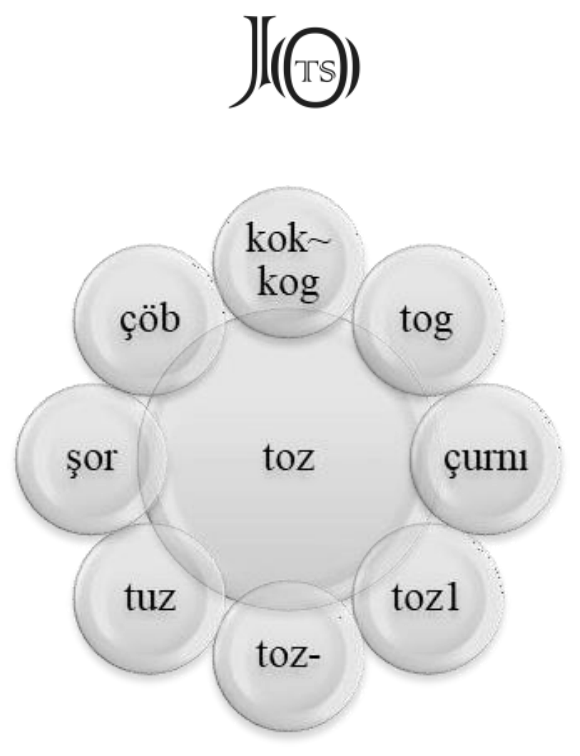

Şekil 9

Burada, toplamda dokuz şekil üzerinden örneklendirilen kök dal biçimlerin anlam odaklı şekil sayısı artırılabilir. Şekil sayısının fazla olması sözcük kök ve gövdelerinin başka bir kökten dal kök biçimlere bölünerek oluştuğu anlamına gelmez. Ayrıca, söz konusu anlam alanındaki sözcüklerin varoluşunun ne kadar eski olduğu hakkında ipucu da verir. Yazı boyunca örneklendirilen kök dal biçimler için bir öncelik-sonralık iddiası bu çalışmanın konusu değildir. Yani, bu çalışma, şu kök dal biçimlerin hepsi şu kökten türemiştir yorumu yerine birbirine koşut olan yapıları saptamayı amaçlamaktadır. Belirli bir anlam alanı çerçevesinde elde edilen kök dal biçimlerden oluşan Tablo 5, farklı anlam alanlarında da yine aynı motivasyonla oluşturulabilir. Burada ilgi çekici olan bir adımsa, aynı yöntemin Ural-Altay dil ailesinde yer almayan başka bir dil üzerinde denenmesi olacaktır. Ancak bu deneme hem bu çalışmanın sınırları hem de amacı doğrultusunda ikinci bir makalenin konusu olmalıdır.

Son söz yerine: Makalenin başlığında da belirtildiği üzere çalışma bir 'yöntem denemesi'dir. Bulguları ve erişileri eleştiriye açık olmakla birlikte alana yeni bir bakış açısı getirmesi amaçlanmıştır.

\section{Kaynakça}

Anderson, L. B. (1987). Adjectival morphology and semantic space. Chicago Linguistic Society. Auwera, J. \& Plungian, V. (1988). Modality's semantic map. Linguistic Typology, 2, 79-124. Brinton, L. J. (2000). The Structure of Modern English. John Benjamins Publishing Company. Bybee, L. J. (1985). Morphology: A study of the relation between meaning and form. Benjamins Press. 
Caferoğlu, A. (1968). Eski Uygur Türkçesi Sözlüğü. Türk Dil Kurumu Yayınları.

Clauson, S. G. (1972). An Etymological Dictionary of Pre-Thirteenth Century Turkish. Oxford University Press.

Croft, W. (1991). Syntactic categories and grammatical relations. The cognitive organization of information. The University of Chicago Press.

Demiryakan, D. (2019). An Etymological Dictionary of Pre-Thirteenth Century Turkish'in Sözcük Yuvaları. İstanbul Aydın Üniversitesi, Sosyal Bilimler Enstitüsü, Türk Dili ve Edebiyatı Anabilim Dalı. (Yayımlanmamış Yüksek Lisans Tezi)

Erdal, M. (2004). A grammar of Old Turkic. Brill.

Eren, H. (1999). Türk Dilinin Etimolojik Sözlüğü. Kişisel Yayın.

Finch, G. (1988). Linguistic Terms and Concepts. Palgrave.

Forchheimer, P. (1953). The Category of Person in Language. Walter de Gruyter \& Co.

François, A. (2008). Semantic maps and the typology of colexification. Lacito (CNRS), 106, 106-163.

Gülensoy, T. (2011). Türkiye Türkçesindeki Türkçe Sözcüklerin Köken Bilgisi Sözlüğü I-II. Türk Dil Kurumu Yayınları.

İmer, K. et al. (2011). Dilbilim Sözlüğü. Boğaziçi Üniversitesi Yayınları.

Jenkins, L. (2000). Biolinguistics Exploring the Biology of Language. Cambridge University Press.

Karaağaç, G. (2013). Dil Bilimi Terimleri Sözlüğü. Türk Dil Kurumu Yayınları.

Karaağaç, G. (2017). Türkçe Üzerine Yazılar. Akçağ Yayınları.

Kocaoğlu, T. (2004). Türk ve Dünya Dillerinde Ses-Anlam Eşitliğine Dayalı Karşıt Denklikler. V. Uluslararası Türk Dili Kurultayı Bildirileri II (pp 1985-2004). Türk Dil Kurumu Yayınları.

Kocaoğlu, T. (2008). Ses-Anlam Eşitlikleri Rastlantısal mı? In Çotuksöken, Y. (Ed.), Uluslararası Dilbilim Kurultayı Bildirileri (pp. 439-449). Maltepe Üniversitesi Yayınları.

Korkmaz, Z. (1992). Gramer Terimleri Sözlüğü. Türk Dil Kurumu Yayınları.

Lessing, F. D. (2017). Moğolca-Türkçe Sözlük. Çev. Karaağaç, G. Türk Dil Kurumu Yayınları.

Liberman, A. (2007). An Analytic Dictıonary of English Etymology. University of Minnesota Press.

Penney, J. H. (2004). Indo-European Perspectives. Oxford University Press.

Roman Jakobson, L. R. (2002). The Sound Shape of Language. Mouton de Gruyter.

Schuessler, A. (2007). ABC Etymological Dictionary. University of Hawai'i Press. 


\section{Ј(ङ)}

Siddiqi, D. \& Harley, H. (2016). Morphological Metatheory. John Benjamins Publishing Company.

Siddiqi, D. (2009). Syntax within the Word economy, allomorphy, and argument selection in Distributed Morphology. John Benjamins Publishing Company.

Türk Dil Kurumu (2015). Türkçe Sözlük.

Vardar, B. (2002). Açıklamalı Dilbilim Terimleri Sözlüğü. Multilingual. 